Anthropocene

Elsevier Editorial system(tm) for

Manuscript Draft

Manuscript Number: ANTHROPOCENE-D-20-00012R1

Title: Spatial conservation prioritization for biodiversity in a megadiverse country

Article Type: Research Paper

Keywords: climate change; deforestation; land-use/cover-change; Mexico; threatened species

Corresponding Author: Dr. Alma Mendoza-Ponce, PhD

Corresponding Author's Institution: Centro de Ciencias de la Atmósfera

First Author: Alma Mendoza-Ponce, PhD

Order of Authors: Alma Mendoza-Ponce, PhD; Rogelio O Corona-Núñez, PhD; Florian Kraxner, PhD; Francisco Estrada, PhD

Abstract: Mexico is a biologically megadiverse country, but its biodiversity is endangered due to high deforestation rates. Impacts of land-use/cover-change and climate change are unevenly distributed, which hinders the execution of conservation practices. Consequently, an adequate spatial conservation prioritization is crucial to minimize the negative impacts on biodiversity. Global and national efforts to prioritize conservation show that $>45 \%$ of Mexico should be protected. This study develops an applicable spatial conservation prioritization to minimize impacts on biodiversity, under three scenarios. They integrate exposure to land-use/cover-change and climate change scenarios, adaptive capacity to deal with the exposure, and the distribution of endemic species on risk of extinction. Our results show that by 2050 between 11.6\%, 13.9\% and 16.1\% of Mexico would reach score $\geq 50$ in vulnerability (VI), under the optimistic, BAU, and the worst-case scenarios, respectively. By 2070, these figures would rise to $11.9 \%$, 14.8\% and 18.4\%. Amphibians are the most threatened vertebrates with $62.2 \%$ of endemic species being critically endangered or endangered, while 39.2\%, 11.8\%, and 8.5\% of endemic mammals, birds and reptiles are endangered or critically endangered. The distribution of these amphibians accounts for 3.3\% of the country's area, while mammals, birds, and reptiles represent 9.9\%, 16.2\%, and 28.7\% of Mexico. Moreover, seven municipalities (0.39\% of the country) represent $30 \%$ of the most vulnerable areas (VI=70). This study offers relevant information at the levels of municipality and species to help decision-makers prioritize national efforts for the conservation of ecosystems and biodiversity under land-use/cover and climate change. This study is replicable in other regions which aim to adapt decision-making and land management for biodiversity conservation. 


\section{Title:}

Spatial conservation prioritization for biodiversity in a megadiverse country

\section{Running title:}

Prioritization of biodiversity conservation

\section{Keywords:}

climate change; deforestation; land-use/cover-change; Mexico; threatened species

\section{List of Authors:}

Mendoza-Ponce, Alma V.; Centro de Ciencias de la Atmósfera (CCA)-UNAM; almamendoza@gmail.com, ORCID: 0000-0002-9069-0652

Corona-Núñez, Rogelio O.; Instituto de Ecología-UNAM; Instituto de Ecología (IE)UNAM, e-mail: rogeliocoronan@yahoo.com.mx, ORCID: 0000-0002-1966-6377

Kraxner, Florian; International Institute for Applied Systems Analysis, ESM, e-mail: kraxner@iiasa.ac.at

Estrada, Francisco.; Centro de Ciencias de la Atmósfera (CCA)-UNAM, e-mail: feporrua@atmosfera.unam.mx

\section{Correspondence author:}

Mendoza-Ponce, Alma V.

\section{Acknowledgments:}

The authors are gratefully for the DGAPA postdoctoral fellowships. Also we want to acknowledge the English editing of Alan Freeman.

\section{Funding sources}

This study was supported by the DGAPA postdoctoral fellowships.

\section{Declarations of interest:}

None

Number of words in the abstract: 263

Number of word in the manuscript as a whole: 7,821 this word counting includes the title (9), abstract (263), figures and table titles (142) and references $(2,375)$.

Number of references: 73

Number of figures: 3

Number of tables: 1

Include annex: Yes 


\title{
Spatial conservation prioritization for biodiversity in a megadiverse country
}

\begin{abstract}
Mexico is a biologically megadiverse country, but its biodiversity is endangered due to high deforestation rates. Impacts of land-use/cover-change and climate change are unevenly distributed, which hinders the execution of conservation practices. Consequently, an adequate spatial conservation prioritization is crucial to minimize the negative impacts on biodiversity. Global and national efforts to prioritize conservation show that $>45 \%$ of Mexico should be protected. This study develops an applicable spatial conservation prioritization to minimize impacts on biodiversity, under three scenarios. They integrate exposure to land-use/cover-change and climate change scenarios, adaptive capacity to deal with the exposure, and the distribution of endemic species on risk of extinction. Our results show that by 2050 between $11.6 \%, 13.9 \%$ and $16.1 \%$ of Mexico would reach score $\geq 50$ in vulnerability (VI), under the optimistic, BAU, and the worst-case scenarios, respectively. By 2070, these figures would rise to $11.9 \%, 14.8 \%$ and $18.4 \%$. Amphibians are the most threatened vertebrates with $62.2 \%$ of endemic species being critically endangered or endangered, while $39.2 \%, 11.8 \%$, and $8.5 \%$ of endemic mammals, birds and reptiles are endangered or critically endangered. The distribution of these amphibians accounts for 3.3\% of the country's area, while mammals, birds, and reptiles represent $9.9 \%, 16.2 \%$, and $28.7 \%$ of Mexico. Moreover, seven municipalities $(0.39 \%$ of the country) represent $30 \%$ of the most vulnerable areas ( $\mathrm{VI}=70)$. This study offers relevant information at the levels of municipality and species to help decision-makers prioritize national efforts for the conservation of ecosystems and biodiversity under land-use/cover and climate change. This study is replicable in other regions which aim to adapt decision-making and land management for biodiversity conservation.
\end{abstract}

Keywords: climate change; deforestation; land-use/cover-change; Mexico; threatened species

\section{Introduction}

Humanity has to address efforts to stop "biological annihilation" based on population decline and species extirpation, which has negative cascading consequences on ecosystem functioning and services (Ceballos et al., 2017; Monsarrat et al., 2019). The loss of biodiversity is the result of several drivers and their interactions, including land-use/cover-change (LUCC), climate change (CC), species invasion and disease (Brook et al., 2008; Sala et al., 2000). However, the effects of CC on the LUCC process and their combined effects on biodiversity are uncertain (Monsarrat et al., 2019; Oliver and Morecroft, 2014). In the tropics, LUCC is expected to be the major force of change, but other studies have suggested that CC may play an important role, particularly for mammals (Paniw et al., 2019). 
Moreover, most of the global biodiversity loss is concentrated in nine countries (Australia, Brazil, China, Colombia, Ecuador, Indonesia, Malaysia, Mexico, and the USA). These elements highlight the necessity for those nations to implement effective monitoring and policy enforcement for species conservation (Alroy, 2017). Mexico is one of the richest countries in biological diversity worldwide. It occupies fourth place in the group of 17 megadiverse countries, whose biodiversity represents around 70\% of known species (Mittermeier et al., 1997; Mittermeier et al., 2011a). However, in the last century it has halved its natural vegetation (Velázquez et al., 2002) due to agricultural and livestock expansion (Bonilla-Moheno, 2012; Mendoza-Ponce et al., 2018). LUCC and CC impacts, as well as affecting biodiversity, are unevenly distributed. Therefore, spatial conservation prioritization is crucial, particularly in megadiverse countries (Brooks et al., 2006), mainly in those countries that suffer from possessing limited technical and economic resources to implement sustainability actions (IPBES, 2019).

Spatial conservation prioritization refers to the use of quantitative techniques to generate spatial information to inform decision-making about an environmental problem. The problem involves choices about spatial allocation to restore or protect important biodiversity areas (Ferrier and Wintle, 2009). Spatial conservation prioritization allows quantitatively ranking locations for conservation purposes (Wilson et al., 2009). For this study, spatial conservation prioritization was implemented to identify the most important regions, ecosystems, and municipalities for species conservation. This process included pragmatic concepts and quantitative approaches based on the criteria of irreplaceability and vulnerability (Margules and Pressey, 2000; Pressey et al., 1994). The irreplaceability of a site has been defined in two ways (Ferrier et al., 2000; Pressey et al., 1994): 1) the likelihood that a site will be required to meet a given set of conservation targets; and 2) the extent to which these targets can be achieved even if the area is lost. These two elements are key for biodiversity conservation. However, the complexity of the term irreplaceability, particularly in biodiversity, should not be reduced to signifying only the number of species, because several areas can share the same number of species. Alternatively, it has been suggested to use endemic species due to their uniqueness (Krupnick and John Kress, 2003; Mittermeier et al., 2011b). Here we evaluate the irreplaceability based on the endemicity of vertebrate species, as has been used in other studies (Loyola et al., 2007). Moreover, vulnerability to climate change is defined as a function of exposure, sensitivity, and adaptive capacity (Adger, 2006), and it expresses the propensity to be adversely affected (IPCC, 2014). However, this definition as well as the vulnerability framework focus especially on human systems (Fortini and Schubert, 2017). Others have defined biological vulnerability as the predisposition to which a species, population or ecosystem is threatened (Dawson et al., 2011). It is important to note that both approaches face practical and theoretical limitations to evaluate the vulnerability of biodiversity. 
The following definitions are adopted to evaluate the vulnerability of biodiversity: 1) Exposure is defined as the degree, duration, and/or extent to which a system, or a part of it is in contact with harm (Adger, 2006); 2) Sensitivity is understood as the susceptibility of an element to be harmed (IPCC, 2014). From a biodiversity perspective, sensitivity was evaluated in terms of the endemicity of the species due to the fact that threatened small-ranged species face larger threats from anthropogenic pressures than more abundant species (Dawson et al., 2011); 3) Adaptive capacity refers to the ability to adjust to current or future conditions (IPCC, 2014). In a socio-ecological context, adaptive capacity integrates biophysical and social or socioeconomic elements.

Over the last decades, different efforts have been undertaken to prioritize biodiversity conservation such as Crisis Ecoregions (Hoekstra et al., 2005), Endemic Bird Areas (BirdLife-International, 2017; Stattersfield et al., 1998), and Important Birds and Biodiversity Areas. The Endemic Bird Areas established that $4.5 \%$ of the Earth is of high priority for broad-scale ecosystem conservation (Stattersfield et al., 1998). Endemic Bird Areas considers 2,500 endemic species, restricted to an area smaller than 50,000 $\mathrm{km}^{2}$. In Mexico there are 22 Endemic Bird Areas and 182 Important Birds Areas and Biodiversity Areas. Endemic Bird Areas represent 1 million $\mathrm{km}^{2}$ with five out of the 22 being shared with neighboring countries. Complementarily, Important Birds and Biodiversity Areas cover an extent of 312,000 $\mathrm{km}^{2}$ representing $15.5 \%$ of the country (BirdLife-International, 2019); The United Nations Environment Program, the International Union for Conservation of Nature and the World Wide Fund for Nature developed a project to identify Centers of Plant Diversity (UNEPWCMC, 2013). The result was that 234 sites were identified, of which 12 are in Mexico, covering $\sim 256,000 \mathrm{~km}^{2}$ (12.8\% of the country). Another important effort is Biodiversity Hotspots, which consists of 34 sites that cover $23.5 \%$ of the Earth's land surface with an extent of $\sim 24$ million $\mathrm{km}^{2}$ (Mittermeier et al., 2011b; Myers et al., 2000). There are three Biodiversity Hotspots in Mexico, and they represent $5 \%$ of the global area of the Biodiversity Hotspots, and $45 \%$ of the total area of Mexico (Californian Floristic Province, Madrean Pine-Oak Woodlands and Mesoamerica). Besides, there is the project focused on wetlands through the RAMSAR convention; Mexico has 142 RAMSAR sites which together comprise $86,570 \mathrm{~km}^{2}$ (4.5\% of Mexico) (RAMSAR, 2015). Moreover, there are national efforts to prioritize biodiversity conservation. The National Commission for the Knowledge and Use of Biodiversity (CONABIO et al., 2007) proposed that up to $43 \%$ of Mexico should be protected. Other Mexican efforts include the Priority Terrestrial Regions ( $\mathrm{n}=152,27 \%$ of Mexico), Priority Marine Regions ( $n=70,71 \%$ of Mexico), Priority Hydrological Regions ( $n=110,40 \%$ of Mexico), and Important Areas for Bird Conservation ( $n=219$, 16\% of Mexico). In terms of prioritization, Priority Terrestrial Regions and Important Areas for Bird Conservation together, propose to conserve $\sim 43 \%$ of the country's terrestrial area. There is also another prioritization exercise focused on restoration, which proposes to restore 15\% of the country (Tobón et al., 2017). However, these global and national efforts face three important difficulties: 1) the coarse spatial 
information makes implementation of any strategy for species conservation difficult; 2) they propose large-extent areas that are unrealistic to address efforts for biodiversity conservation at, and 3) they fail to include future threats such as LUCC and CC.

Mexico has highly heterogeneous ecosystems, climates, and cultural diversity. This context sets a challenge for biodiversity conservation. Therefore, the objective of this study was to identify priority sites for biodiversity conservation, considering two of the most important threats to biodiversity, LUCC and CC. To reach this objective we posed the following key questions.

(Q1) To what extent is the vulnerability and the irreplaceability framework an alternative to reduce the total protected area proposed by the previous global and national efforts to prioritize biodiversity conservation?

(Q2) What are the key ecosystems and regions that may drive major species extinctions under LUCC and CC scenarios?

\section{Methodology}

This section is divided into two parts. The first focuses on the modeling of land-use/cover-change (LUCC) under socioeconomic and climate change (CC) scenarios. The second part shows the development of the prioritization steps under the vulnerability and irreplaceability framework. This framework includes exposure to LUCC and CC, sensitivity, and adaptive capacity. The study considers the terrestrial part of Mexico $\left(1,932,524 \mathrm{~km}^{2}\right)$ at a $1-\mathrm{km}^{2}$ resolution and three contrasting LUCC and CC scenarios that represent an optimistic one, a business-as-usual one (BAU), and an optimistic and worst-case scenario.

\section{II.1 LUCC modelling}

The LUCC models were developed using Dinamica EGO (version 3.0.17.0). This software was selected due to its capacity to implement dynamic processes, including feedbacks between LUCC and CC. The models included calculations of transition matrices, colinearity of the variables, the estimation of the weights of evidence of explanatory variables, short-term projection for validating the model and long-term projections. The estimated models were independently validated by comparing the observed and the simulated maps, following the approach of Soares-Filho et al. (2009), based on an exponential and multiple-window constant decay function.

The land-use/land-cover classification maps come from the most complete and detailed information source in Mexico. These maps were developed by the National Institute of Statistics and Geography (INEGI) for the years 1985, 1993, 2002, 2007, 2011 and 2015. All of the maps were reclassified in thirteen common land-use/land-cover classes. These classes consisted of eight natural covers (cloud forest, grassland, hydrophilic vegetation, scrubland, temperate forest, tropical evergreen forest, 
tropical dry forest, and other vegetation types); four anthropogenic covers (pastures, irrigated agriculture, rainfed agriculture and urban); and one for barren land (Mendoza-Ponce et al., 2018).

A set of 24 explanatory variables (13 socioeconomic and 11 biophysical; Table A.1) were selected to represent the main drivers of change. The socioeconomic data consist of population and Gross Domestic Product and were obtained from the national census from INEGI while the projections for these variables are from the International Institute for Applied Systems Analysis (IIASA, 2016). The future socioeconomic information (Shared Socioeconomic Pathways - SSPs) was downscaled at the municipality level by assuming a constant representation over time, based on the mean historical share of each municipality. Finally, all of the historical climatic variables and the $\mathrm{CC}$ scenarios based on the Representative Concentration Pathways (RCPs) were downloaded from Worldclim (Fick and Hijmans, 2017). Three combinations of socioeconomic and climate scenarios were considered for this study: a business-as-usual (BAU) which includes the combination of the SSP2 and RCP4.5; an optimistic scenario which integrates the SSP1 and RCP2.6; and a worst-case scenario that combines the SSP3 and the RCP 8.5.

Each LUCC projection was modeled by integrating the corresponding socioeconomic and climatic variables, and differential LUCC rates. The optimistic, the BAU, and the worst-case climate scenarios (RCP2.6, RCP4.5, and RCP 8.5 ) include four General Circulation Models (CNRMC-M5; GFDLCM3; HADGEM2-E5; MPI-ESM-LR), and two time horizons: 2050s (average for 2041-2060) and 2070s (average for 2061-2080) (Mendoza-Ponce et al., 2018). The set of General Circulation Models was selected to match those used in the current national climate change technical documents (INECC, 2019). The rates of deforestation were calculated using the Food and Agriculture Organization recommendations (FAO, 1995), and using the national land-use/cover maps available at the most aggregated categories (Mendoza-Ponce et al., 2018).

Future maps of land-use/land-cover were produced from each General Circulation Model, and the level of agreement between the projected patterns of change was evaluated. The evaluation of agreement between the maps considered deforestation, regeneration and permanence. The same process was applied to each combination of SSP and RCP scenarios described above. The level of agreement between the models is expressed in percentages for each of the pixels. Values between $75 \%$ and $100 \%$ denote concordance in projected deforestation, regeneration or permanence of any modeled transition of LUCC in at least three out of four General Circulation Models.

\section{Business-as-usual (BAU) scenario}

This scenario uses the SSP2 assumptions - defined as "middle of the road" - in which social, economic, and technological trends do not change markedly from historical patterns (O'Neill et al., 
2017; Riahi et al., 2017). In terms of demography, Mexico is considered a low fertility country (O'Neill et al., 2017), with moderate mortality and migration (Kc and Lutz, 2017; O'Neill et al., 2017). Similarly, economic growth is moderate, with significant contrasts across the country. These factors promote the likelihood that the LUCC trends fall within the middle of the historical records. To incorporate the LUCC trajectories quantitatively, we considered the national land-use maps (INEGI, 1985, 1993, 2002, 2007, 2011, 2015) to estimate the mean rates of change from all the combinations of every single transition (Table A.2). This process was implemented to define the baseline trajectory and to minimize the bias of selecting a specific time period (Pana and Gheyssens, 2016). All the climatic data were updated to correspond to the scenario and the time horizon (2050s and 2070s) to model (Fick and Hijmans, 2017).

\section{Optimistic scenario}

The SSP1 storyline is considered a sustainable path (O'Neill et al., 2017) characterized by a consumption-oriented transition toward low materialistic growth with efficient use of resources and energy, with a significant reduction of tropical deforestation (Popp et al., 2017). The SSP1 socioeconomic scenario depicts low fertility, mortality, and migration leading to a rapid demographic transition for countries like Mexico (Kc and Lutz, 2017; O’Neill et al., 2017). In terms of economy, SSP1 reflects shifts toward a broader emphasis on human wellbeing. The GDP growth is lower than in the SSP2 scenario, but the low population growth of the SSP1 results in a reduction of the inequality. The SSP1 scenario is combined with the RCP2.6 for climate projections. The optimistic scenario also assumes the lowest historical deforestation rates of all the ecosystems and the highest historical regeneration rates (Table A.3). As such, this scenario supports an optimistic development within feasible social and economic trajectories and integrates possible national policies to reduce deforestation and degradation, as well as to promote regeneration as a biodiversity conservation strategy.

\section{Worst-case scenario}

The SSP3 refers to a fragmented world with an emphasis on security at the expense of international development (Riahi et al., 2017). Population will grow rapidly in developing countries, including Mexico, but slowly in rich OECD countries. This scenario assumes high mortality and low education (Kc and Lutz, 2017). In terms of land-use, the SSP3 assumes high deforestation rates and large expansions of cropland and pasture land, as compared with SSP1 (Fujimori et al., 2017). The SSP3 scenario is combined with the RCP 8.5 which assumes the highest levels of greenhouse gases emissions. This scenario projects the worst deforestation rates and the lowest regeneration rates for all the ecosystems in Mexico (Table A.3) based on the need for agricultural and pastureland expansion to fulfill food demand. 


\section{2 Exposure}

The exposure to LUCC was estimated considering the propensity of an area to change from natural cover to anthropogenic cover for both scenarios and for all of the General Circulation Model projections. To identify the changing areas over time (2011-2050 and 2011-2070), the LUCC models were reclassified (natural $v s$ no-natural). The resulting integrations identify the permanence of natural covers or anthropogenic covers, loss of natural vegetation, and regeneration. These transitions are related to an exposure value, where a value of 100 refers to areas that are prone to be converted to anthropogenic covers, while a value of 50 relates to areas prone to regeneration, because these areas are more predisposed than old-forested lands to being deforested again, as suggested by Rudel et al. (2005). Meanwhile, a value of zero identifies areas with permanence of natural vegetation, where, consequently, there is a null exposure to LUCC.

The exposure to $\mathrm{CC}$ was estimated as the difference between current and future scenarios of each of the two climatic variables: 1) Mean annual temperature (BIO1), and 2) annual precipitation (BIO12). The resulting values were normalized between 0 and 100 (Equation 1), where 100 denotes the largest future difference in relation to the current values and zero refers to no change. The integration of the exposure to LUCC and CC was estimated by equally weighting both exposures.

Eq. 1.

$$
N=\frac{\left(X_{i}-X_{m}\right)}{\left(X_{M}-X_{m}\right)}
$$

Where $\mathrm{N}$ is the normalized value between 0 and $100, \mathrm{X}_{i}$ is the observed value, $\mathrm{X}_{m}$ is the minimum value observed and $\mathrm{X}_{M}$ is the maximum value observed in the data set (Monterroso and Conde, 2015).

\section{II.3 Sensitivity and adaptive capacity}

We use IUCN's biodiversity spatial data for terrestrial vertebrates (mammals, reptiles, amphibians) (IUCN, 2017) and birds (BirdLife-International, 2017). All the information was rasterized to a spatial resolution of $1-\mathrm{km}^{2}$, and from this we calculated: 1) the total richness and richness by group, and 2) the number of endemic and critically endangered or endangered species. For each group, we normalized the data between 0 and 100 , where a value of 100 refers to the areas with the highest number of endemic species that are critically endangered or endangered.

Adaptive capacity was estimated using the Conservation Risk Index proposed by Hoekstra (2005). We selected this index because it expresses the capability of a region to face the challenges to overcome the impacts of the anthropogenic pressures. This index is the ratio of the percentage of 
converted area (natural to anthropogenic), and the percentage of protected areas. The adaptive capacity was estimated at the finest possible resolution which is the municipality level for the current and future conditions based on the BAU and the optimistic scenarios. The final ratio was normalized between 0 and 100. The highest value refers to the municipalities with an absence of protected areas, which suggests the lowest adaptive capacity to cope with biodiversity loss. Values close to zero denote municipalities in which deforestation is equal to or smaller than the total extent of the protected areas within the same municipality.

\section{II.4 Vulnerability}

The vulnerability index was calculated as a mean of exposure, sensitivity, and adaptive capacity (Eq.2). Values close to 100 refer to areas prone to be converted from natural to anthropogenic covers with the largest changes in the climatic variables (temperature and precipitation), absence in protected areas and with the presence of endemic and endangered vertebrates. In contrast, figures close to zero refer to sites that will face low risk of deforestation, with small changes in climate and with no endemic and endangered vertebrates.

Eq. 2

$$
\text { Vulnerability }=\frac{\text { Exposure }+ \text { Sensitivity }+ \text { Adaptive Capacity }}{3}
$$

\section{Results \\ III.1 Exposure}

Exposure to land-use/cover-change (LUCC) shows that natural vegetation accounted for up to $72.2 \%$ of Mexico's area in 2011. However, according to the business-as-usual (BAU) scenario, by 2050 and 2070 , natural covers would cover $62.9 \%$ and $60.5 \%$ of the country, respectively. In the worst-case scenario only $14.1 \%$ and $12.2 \%$ of Mexico would remain as natural cover. In contrast, the optimistic scenario shows a slight recovery for 2050 and 2070, suggesting that it is possible to increase the forested area to account for $78.8 \%$ and $79.2 \%$ of the country. The areas with the highest exposure to LUCC are on the Pacific Coast and the Peninsula of Yucatan (Fig 1, Fig. A.1, Fig. A.2, and Fig. A.3). In those regions, the tropical dry forests are in frontier with tropical evergreen and temperate ecosystems. In contrast, in the worst-case scenario, there are agricultural and livestock expansions in the Sierra Madre Occidental and Sierra Madre del Sur (Fig. A.2). These areas are mainly represented by temperate and cloud forests.

The exposure to climate change (CC) suggests an increment in temperature and, for the most part of the country, a reduction in precipitation. According to RCP2.6 and the four General Circulation Models, by $205073 \%$ of Mexico will show increases in annual temperature between $1.7^{\circ} \mathrm{C}$ and $2.3^{\circ} \mathrm{C}$. Furthermore, $75 \%$ of the country is depicted experiencing increments between $2.0^{\circ}-2.6^{\circ} \mathrm{C}$ by 2050 
and between $2.4^{\circ}-3.2^{\circ} \mathrm{C}$ by 2070 , under the RCP4.5. By 2050, the RCP 8.5 projects increments between $3.0^{\circ} \mathrm{C}$ and $3.8^{\circ} \mathrm{C}$ in $73 \%$ of the country, and by 2070 there could be an increase of $3.6^{\circ} \mathrm{C}$ to $4.6^{\circ} \mathrm{C}$ in $76 \%$ of Mexico. The largest increments are projected in small areas at the mountain chains which are dominated by temperate forest, and in different regions, as in the Northwest and Northeast of the country that are dominated by scrublands and deserts. In the worst-case scenario the most affected area is in the north where the states of Sonora and Chihuahua are in the Sierra Madre Occidental and North Altiplano (Fig. A.1, A.2 and A.4).

Precipitation shows great variability among the General Circulation Models projections. It is expected that Mexico would show a rise in precipitation $>5 \%$ in $28 \%, 27 \%$ and $17 \%$ of the country, according to the RCP2.6, RCP4.5, and RCP8.5 respectively. These changes occur in the Central American mountain chain (Isthmus of Tehuantepec) and in the lower part of the East mountain chain (Sierra Madre Oriental). Contrastingly, by 2050 and 2070, 9\% and $10 \%$ of the country would show a decrease in precipitation $(>3 \%)$ under the BAU and the optimistic scenarios, particularly in the Central area of the Sierra Madre Oriental and the North-Gulf coastal plains (Fig. A.2 and A.5). Also, by 2070 , a reduction in the precipitation is expected, $>5 \%$, in $12 \%$ and $13 \%$ of Mexico, and an increment $>3 \%$ in $16 \%$ and $20 \%$ of the country, according to RCP2.6 and RCP4.5 respectively (Fig 1). The worst-case scenario shows decreases $\geq 5 \%$ in $37 \%$ and $68 \%$ of the country by 2050 and by 2070. The cumulative exposure of both threats, LUCC and CC, shows that by $20505 \%, 12 \%$ and $27 \%$ of Mexico would experience a score value $>50$ for the optimistic, BAU and worst-case scenarios respectively (Fig. A.5). The areas with the largest exposure to LUCC and CC are located around the Pacific coast where the tropical dry forest is distributed, and the Central Altiplano (or high plains) close to the Central Volcanic Belt (Fig. A.2), which is dominated by natural grasslands bordered with temperate forests and the Yucatan Peninsula.

\section{III.2 Sensitivity}

According to the IUCN (2017), Mexico has 256 species of endemic and critically endangered or endangered terrestrial vertebrates (56 mammals, 154 amphibians, 12 birds, and 34 reptiles) (Table A.4). Of these, amphibians are the most threatened vertebrates, with $62 \%$ of endemic amphibians considered critically endangered or endangered. In a similar manner, 39\%, 12\%, and 9\% of the endemic mammals, birds, and reptiles, are endangered or critically endangered (Table 1). The dominant ecosystems constraining the endemic vertebrates are temperate forests, followed by scrublands, tropical dry forests, and natural grasslands. Interestingly, about $30 \%$ of the distribution of these species converged with disturbed regions such as in rain-fed-agriculture and pasturelands covers (Fig. 2). 
The distribution of the threatened amphibians accounts for 3.3\% of the country, while mammals, birds and reptiles in these categories represent 9.9\%, 16.2\%, and 28.7\% of the country (Fig 1). Endemic and endangered or critically endangered amphibians are principally distributed over the southern coasts of the country (Pacific and Gulf of Mexico) (Fig. A.1 and Fig. A.6). This region is represented by tropical rainforests, temperate forests and cloud forests (Fig. A.2). The endemic and the endangered or critically endangered mammals are spread across the Baja California Peninsula, part of the Southern Pacific Coast and the Gulf of Mexico in the southern part of the State of Veracruz. In contrast, endemic endangered or critically endangered birds are located on the Sierra Madre Occidental and in the Central Volcanic Belt (Fig. A.2). These regions show the largest extension of temperate forests. Additionally, endemic and endangered or critically endangered reptiles are mainly restricted to the arid ecosystems such as scrublands and natural grasslands in the northern and eastern central part of Mexico (Fig A.2 and Fig. A.6).

The bird group exhibits the highest species density (446 species per $\mathrm{km}^{2}$ ). Most of this richness is found in the south of Mexico, South Gulf Coastal Plain, Sierra Madre del Sur, and the Central American mountain chain (Fig. A.2 and A.6), which are characterized by tropical rainforest, cloud forest, and are within the transition to temperate forests. The mountain chains (Sierra Madre Oriental and Sierra Madre Occidental), dominated by temperate forest, turned out to be the most important areas in terms of endemic and threatened species. The mammal group shows the second highest species density (139 species per $\mathrm{km}^{2}$ ), and is represented especially in the southeastern tropical rainforest in the Sierra Madre del Sur, and in the border with Central American mountain chain (Fig. A.2 and A.6). These areas with high levels of biological richness are close to ecotones between temperate, cloud and tropical rainforests. In terms of endemic and threatened species the more diverse areas are in temperate forests (Central Volcanic Belt, such as Pico de Orizaba and Cofre de Perote), and the tropical dry forests (Pacific Coast, particularly in the Chamela region; Fig. A.1, Fig. A.2 and A.6).

Reptiles are the third group in terms of species density. The maximum richness is 59 species per $\mathrm{km}^{2}$ and these are located in two regions: a tropical rainforest in the Gulf of Mexico (Los Tuxtlas), and the scrublands in northern Mexico (Cañón de Santa Elena). Moreover, the richest areas dominated by endemic and threatened density of reptile species were found in the eastern scrublands (Sierra Madre Oriental mountain chain (Fig. A.2 and A.6). Finally, amphibians had the lowest species density with a maximum of 32 species per $\mathrm{km}^{2}$. This richness was observed in the tropical evergreen forests in the Gulf of Mexico (Los Tuxtlas). Eight species is the maximum number of endemic and threatened amphibians registered in temperate forests (Central Volcanic Belt as Pico de Orizaba, Cofre de Perote and Sierra Madre del Sur), and cloud forests (State of Guerrero) (Fig. A.1 and A.6). However, it is 
important to highlight that Chamela and Los Tuxtlas have two of the most important ecological research stations in Mexico (Fig. A.1), which may bias these numbers.

Table 1. Number of vertebrate species classified as critically endangered or endangered vertebrates in Mexico**

\begin{tabular}{|l|r|r|r|r|}
\hline & Amphibians & Mammals & Birds & Reptiles \\
\hline Total & 372 & 466 & 1040 & 691 \\
\hline Endemic & 246 & 143 & 93 & 399 \\
\hline Critically endangered & 91 & 26 & 7 & 3 \\
\hline Endangered & 84 & 37 & 16 & 36 \\
\hline Endemic critically endangered & 81 & 26 & 4 & 1 \\
\hline Endemic endangered & 72 & 30 & 8 & 33 \\
\hline
\end{tabular}

371

**The figures in the table were calculated for the continental land, including major islands and excluding small islands of Mexico. These data contrast with the latest BirdLife-International (2019) report which included 64 new species for Mexico, with a total of 118 endemic species

\section{III.3 Adaptive capacity}

The areas with less adaptive capacity (high conservation risk index) are in the Central Volcanic Belt and the Central Altiplano, the South Pacific coast, the northwest area in the Sonoran Desert, and the Sierra Madre Oriental (Fig 1 and Fig. A.2 and A.3). These areas overlap with the most important cities of the country and the highest populated areas. Moreover, $56 \%, 70 \%$, and $72 \%$ of the Mexican municipalities, accordingly to the optimistic, BAU and worst-case scenarios, show high critical risk index $(\geq 90)$ and low adaptive capacity. These areas are mainly located in scrublands, temperate and tropical dry forests, suggesting a need to increase the protected areas in these ecosystems to prevent deforestation. 


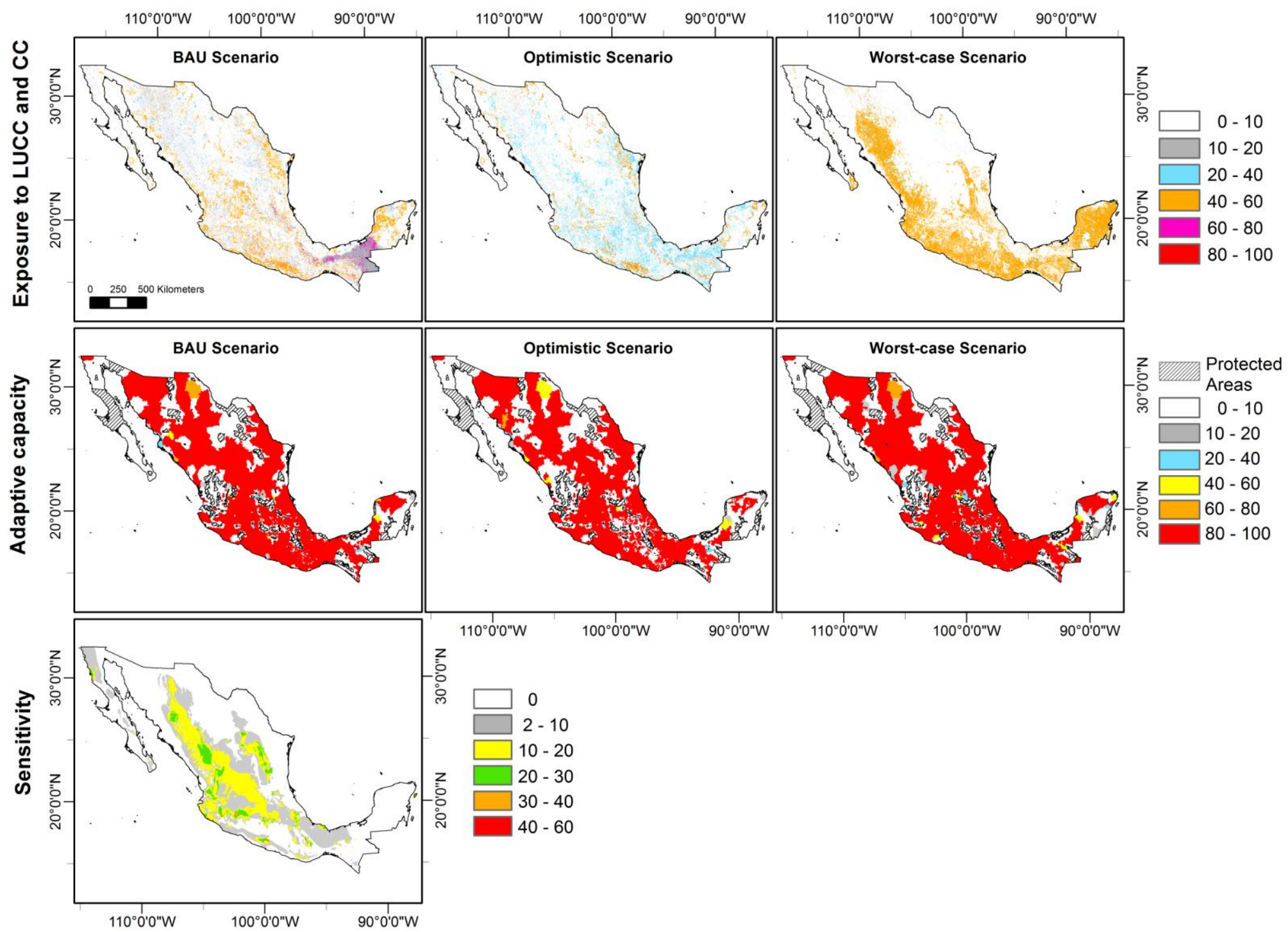




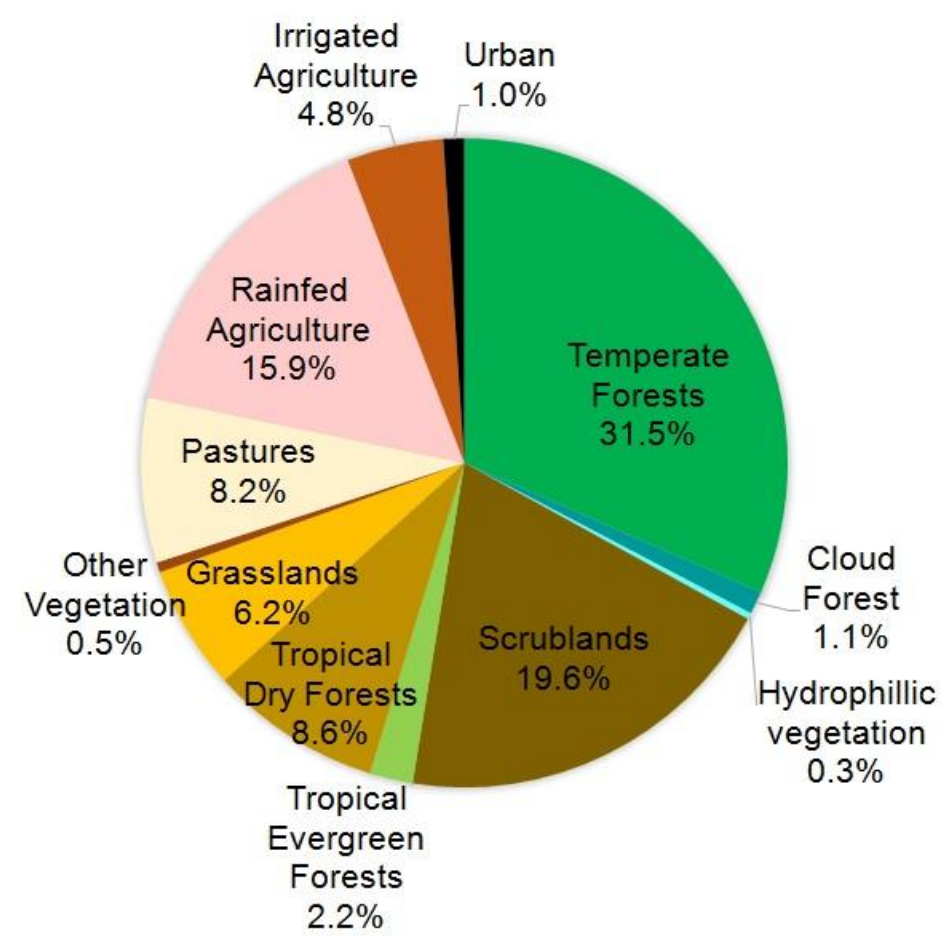

Fig 2. Endemic, critically endangered, and endangered species of vertebrates by land-use/cover in Mexico.

\section{III.4 Vulnerability}

The estimates of vulnerability range from very low (0) to high (80) and $42.6 \%$ of the country shows moderate to high vulnerability. By 2050, between $8.2 \%, 10.4 \%$ and $16.1 \%$ of Mexico shows a vulnerability index value $\geq 50$, depending on which scenario is assumed (optimistic, BAU and worstcase). By 2070 , these figures increase to $8.4 \%, 10.9 \%$ or $18.1 \%$ for each scenario respectively (Fig 3). There are 167 out of the 2,457 Mexican municipalities that reach the highest vulnerability scores (70) in the BAU scenario. In the worst-case scenario, the highest vulnerability value was 80 and four municipalities are in this category, while 452 score 70 in this index. Of those, seven municipalities represent $30.4 \%$ of the most vulnerable areas and $0.39 \%$ of the country's land. These municipalities are mainly in the state of Guerrero (Fig. A.1).

In Mexico, 3.5\% and 6.7\% of the pasture lands for cattle raising, and rainfed-agriculture match the most vulnerable areas for biodiversity conservation in the BAU scenario, while these figures increase to $5.4 \%$ and $8.9 \%$ in the worst-case scenario. From an ecosystem perspective, cloud forests, followed by tropical dry forests and natural grasslands are the most affected under the BAU and optimistic scenarios. Temperate forests are the most vulnerable ecosystems in the worst-case scenario, especially because of their high exposure to LUCC which can be reinforced with CC pressure. The most vulnerable portion of cloud forest is distributed along the Pacific Coast (states of Guerrero, Oaxaca, and Chiapas). The same pattern was found for the tropical dry forests and temperate forests in the 
states of Jalisco, Michoacán, Guerrero, and Oaxaca. In the case of natural grasslands, the most 414 vulnerable areas are restricted to three regions (northeast of Jalisco, east of Durango and west of 415 Zacatecas; Fig 3 and Fig. A.1).

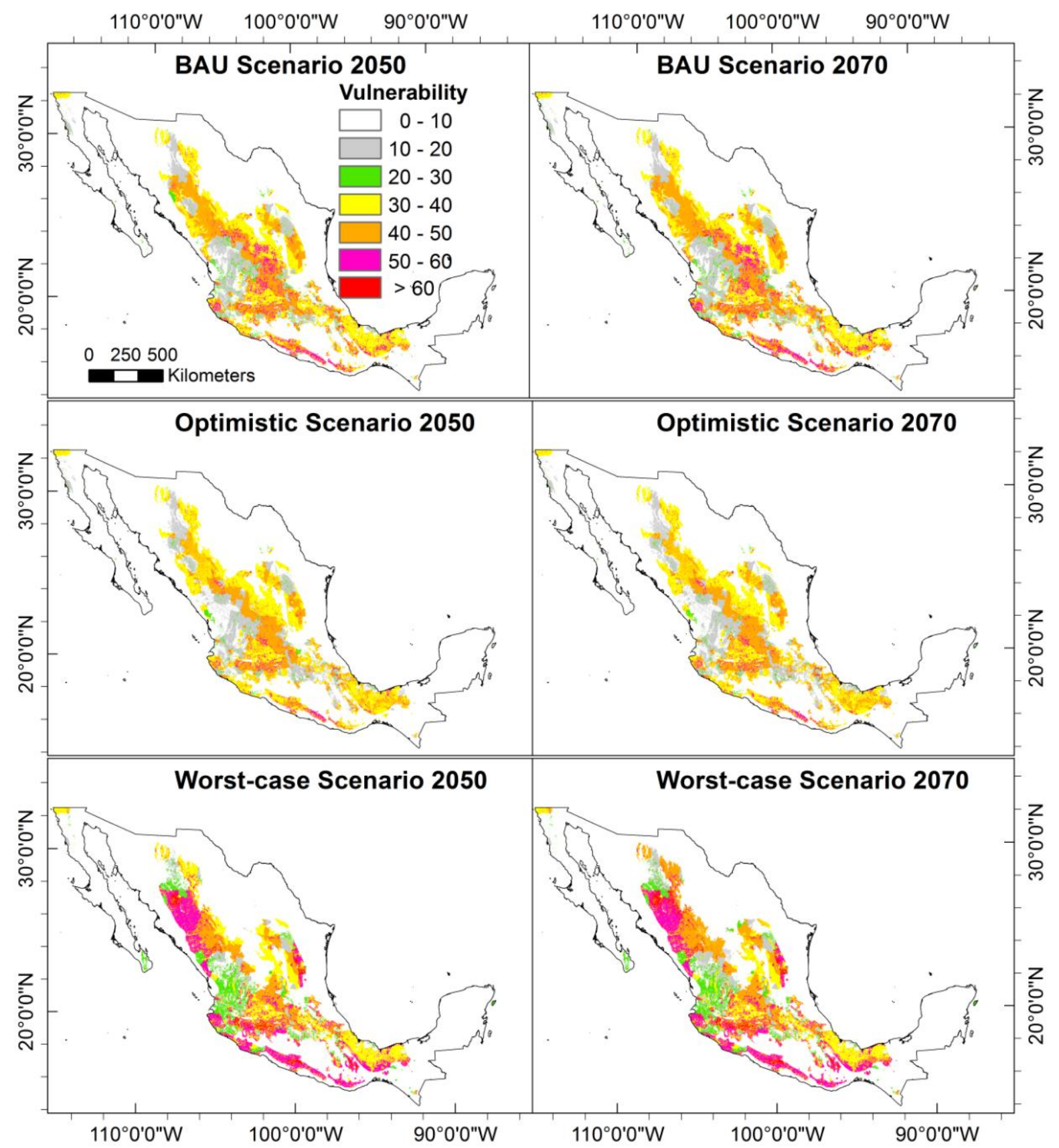

Fig 3. Vulnerability maps by 2050 and 2070 for the business-as-usual (BAU), optimistic and worstcase scenarios for Mexico.

422 Human activities, especially land-use/cover-change (LUCC), are causing a decline in global biodiversity (Newbold et al., 2015) which is reinforced by climate change (CC) (Oliver and 
Morecroft, 2014). These processes increase the pressures of global, regional or local threats to the biodiversity. Therefore, it is necessary to develop innovative approximations to prioritize locations for biodiversity conservation (Brooks et al., 2006; Monsarrat et al., 2019) particularly under LUCC and $\mathrm{CC}$ scenarios to avoid the extinction of endemic species.

Our results show that under an optimistic scenario it is possible to experience a slight recovery of natural vegetation of $6.6 \%$ and $7.0 \%$ by 2050 and 2070 respectively. But to reach this goal there should be a combination of several factors that need to be reinforced, such as low or moderate population growth, which in turn is related to resources consumption (Riahi et al., 2017). In contrast, the BAU scenario shows a reduction of natural vegetation of $9.3 \%$ and $11.7 \%$ for the same time periods, mainly as a result of the agricultural expansion to satisfy the future national and international demands of crops and livestock. This highlights the importance of defining innovative local protection strategies to reduce the risk of species extinction. Moreover, it is relevant to promote management focused on a sustainable processes to improve agricultural practices to reduce the pressure on natural vegetation. Nevertheless, it is important to point out that future studies should evaluate not only the implications of agricultural intensification as an alternative, but also the inclusion of native varieties of crops and different management practices like agroforestry.

In recent years Mexico has expanded its protected areas in number and total area. However, they face important challenges to achieve effectiveness (Figueroa and Sánchez-Cordero, 2008; Watson et al., 2014). Mexico has 182 protected areas, of which 145 are terrestrial, representing $10.6 \%$ of the country. But more than half of these terrestrial protected areas are restricted to protect temperate forests and scrublands. While this may relate to the fact that Mexico is the country with the highest diversity of pines and oaks in the world (Rodríguez-Trejo and Myers, 2010), this does not reflect the real national needs for protection and/or conservation. Consequently, this study highlights the need to expand conservation practices towards other ecosystems that are underrepresented within the protected areas, such as tropical dry forests and natural grasslands, accounting for $8 \%$ and 5\% respectively. Similar observations were previously made for Mexico and the globe (Linares-Palomino et al., 2011). Moreover, over different spatial scales it has been recognized that the Mexican tropical dry forest is at risk of high exposure to both LUCC (Corona et al., 2016; Mendoza-Ponce et al., 2018), and CC (Prieto-Torres et al., 2016). The same holds true for natural grasslands (Henwood, 2010; IUCN, 2014). However, none of the previous studies took into consideration the biodiversity of those ecosystems. Therefore, from an ecosystem perspective, there is a need to reinforce conservation management in three regions: 1) the south of the Mexican Pacific coast (tropical dry forests); (2) the Central Volcanic Belt (temperate forests); and (3) the natural grasslands bordering the eastern part of the Sierra Madre Occidental. 
Exposure to LUCC and CC can be quantified in spatial and temporal dimensions. However, adaptive capacity and sensitivity are concepts that are challenging to characterize in an ecological context (Fortini and Schubert, 2017) and even more to be spatially explicit about. The adaptive capacity depends on ecosystems, communities, species, populations, individuals and genes (Hoffmann and Sgrò, 2011). At the ecosystem level, it has been shown that, in contrast to grasslands, forests and scrublands are influenced in terms of presence of species and by the size of the patches (Keinath et al., 2017). Moreover, at the species level, it is possible to find characteristics that allow high capacity, but at the same time, these traits confer a decrease in sensitivity (Williams et al., 2008). However, at the genetic level, fragmentation due to LUCC dynamics also affects evolutionary processes by modifying the flow of genes and reducing the introduction of novel genotypes into populations through hybridization (Hoffmann and Sgrò, 2011).

From a socio-ecological perspective, the ability to adapt to future challenges should include biophysical elements and different socioeconomic factors related to human decisions (Lindner et al., 2010). Consequently, finding indicators for assessing adaptive capacity based on socio-ecological traits is challenging, especially for large regions. In this context, the ratio between habitat conversion and habitat protection is a simple, helpful and informative metric of the adaptive capacity. This index assumes that areas where protection is higher than the anthropogenic conversion of land exert less pressure on the environment. However, there is the risk that these areas may be exporting their environmental pressures to other places (Lambin and Meyfroidt, 2011). In the Mexican context, almost half of the LUCC process is driven by the expansion of rainfed-agriculture, mainly related to internal consumption (Mendoza-Ponce et al., 2018). The adaptive capacity shows that more than 50\% of Mexican municipalities have an ecological deficit, resulting in higher forest losses than are being protected. This suggests that most Mexican municipalities are challenged to protect their biodiversity with significant implications for potential species extinctions. Therefore, future land-management should take into consideration not only the protection of ecosystems, but also specific areas dominated by endemic and threatened species. And further studies should assess the potential effectiveness of conservation practices under different anthropogenic practices.

Sensitivity was conceptualized as a spatial characteristic that integrates endemicity and threat, on the basis that areas with more endemic and endangered species would be more affected by significant habitat loss and newer climate threats (Swab et al., 2012). However, assessing sensitivity as a spatial indicator cannot fully express the complexity of the ecological criteria, mainly due to the contrasting differences across the biological taxa (Williams et al., 2008). Species richness is an indicator to prioritize biodiversity conservation but it poses important challenges such as the large variability depending on the scale of analysis, taxonomic grouping, estimation methods, and the dynamic nature 
differently under LUCC and CC (Brodie et al., 2012; Kara et al., 2017; Monsarrat et al., 2019; Paniw et al., 2019).

Finally, this study shows that there are clear limitations to the integration of spatial indicators for adaptive capacity and sensitivity for biodiversity assessment. However, until more data become available with a higher degree of detail, our results indicate that it is possible to prioritize areas for a feasible biodiversity conservation practice for the two most important threats. Moreover, the proposed framework is reproducible, transparent and flexible to adapt, and comparable across different ecosystems and regions.

\section{Conclusions}

This study proves that modelling is critical for biodiversity conservation by identifying future vulnerable areas and species in complex systems. The methodology presented here allows it to be replicable in other regions, which is fundamental for decision-making and land management. Moreover, (Q1) this study shows that the vulnerability and the irreplaceability framework is a useful alternative to identify areas to prioritize biodiversity conservation. This framework can be implemented over different spatial scales by the inclusion of direct threats to biodiversity and indirect drivers of change. Our study allows the reduction of global and national proposals of conservation for Mexico from $43 \%$ of the country to less than 19\%. (Q2) Cloud forests and natural grasslands are highly vulnerable to land-use/cover-change and climate change in all periods, although temperate forests and tropical dry forests were shown to be strongly affected in some of the combinations of the historical periods. Besides, we highlight that seven municipalities out of the 2,456 , represent $30.4 \%$ of the most vulnerable areas. This information can help prioritization of local monitoring actions of populations of threatened species. In this regard, we propose strategies to reduce the risk of extinction, such as: 1) defining new protected areas in regions that have critically endangered populations with small range distribution; 2) creation of biological corridors to allow genetic flow; 3) prioritization of the restoration of patches to ensure biodiversity conservation; 4) the design of studies and policies aiming at understanding and mitigation of local impacts of LUCC and CC; 5) preventing negative impacts of invasive species; and 6) the design of strategies for protecting the genetic variability of threatened populations.

\section{References}

Adger, W. N. (2006). Vulnerability. Global Environmental Change 16, 268-281.

Alroy, J. (2017). Effects of habitat disturbance on tropical forest biodiversity. Proceedings of the National Academy of Sciences 114, 6056-6061.

BirdLife-International (2017). Country profile: Mexico (B. Organization, ed.).

BirdLife-International (2019). Country profile: Mexico. 
Bonilla-Moheno, M., Aide, T. Mitchell, Clark, Matthew L. (2012). The influence of socioeconomic, environmental, and demographic factors on municipality-scale land-cover change in Mexico. Regional Environmental Change 12, 543-557.

Brodie, J., Post, E., and Laurance, W. F. (2012). Climate change and tropical biodiversity: a new focus. Trends in Ecology \& Evolution 27, 145-150.

Brook, B. W., Sodhi, N. S., and Bradshaw, C. J. A. (2008). Synergies among extinction drivers under global change. Trends in Ecology \& Evolution 23, 453-460.

Brooks, T. M., Mittermeier, R. A., da Fonseca, G. A. B., Gerlach, J., Hoffmann, M., Lamoreux, J. F., Mittermeier, C. G., Pilgrim, J. D., and Rodrigues, A. S. L. (2006). Global Biodiversity Conservation Priorities. Science 313, 58.

Ceballos, G., Ehrlich, P. R., and Dirzo, R. (2017). Biological annihilation via the ongoing sixth mass extinction signaled by vertebrate population losses and declines. Proceedings of the National Academy of Sciences 114, E6089-E6096.

CONABIO, CONANP, TNC, Pronatura, FCF, and UAN L. (2007). "Análisis de vacíos y omisiones en conservación de la biodiversidad terrestre de México: espacios y especies" Comisión Nacional para el Conocimiento y Uso de la Biodiversidad, Comisión Nacional de Áreas Naturales Protegidas, The Nature Conservancy-Programa México, Pronatura, A.C., Facultad de Ciencias Forestales, Universidad Autónoma de Nuevo León, México., México.

Corona, R., Galicia, L., Palacio-Prieto, J. L., Bürgi, M., and Hersperger, A. (2016). Local deforestation patterns and driving forces in a tropical dry forest in two municipalities of southern Oaxaca, Mexico (1985-2006). Investigaciones Geográficas, Boletín del Instituto de Geografía 2016, 86-104.

Dawson, T. P., Jackson, S. T., House, J. I., Prentice, I. C., and Mace, G. M. (2011). Beyond Predictions: Biodiversity Conservation in a Changing Climate. Science 332, 53.

FAO (1995). "Forest resources assessment 1990. Global Synthesis." Food and Agriculture Organization of the United Nations.

Ferrier, S., Pressey, R. L., and Barrett, T. W. (2000). A new predictor of the irreplaceability of areas for achieving a conservation goal, its application to real-world planning, and a research agenda for further refinement. Biological Conservation 93, 303-325.

Ferrier, S., and Wintle, B. (2009). Quantitative Approaches to Spatial Conservation Prioritization: Matching the Solution to the Need. In "Spatial Conservation Prioritization. Quantitative Methods \& Computational Tools." (M. Atte, W. Kerrie and P. Hugh, eds.), pp. 1-15. Oxford University Press, New York.

Fick, S. E., and Hijmans, R. J. (2017). WorldClim 2: new 1-km spatial resolution climate surfaces for global land areas. International Journal of Climatology, n/a-n/a.

Figueroa, F., and Sánchez-Cordero, V. (2008). Effectiveness of natural protected areas to prevent land use and land cover change in Mexico. Biodiversity and Conservation 17, 3223-3240.

Fleishman, E., Noss, R. F., and Noon, B. R. (2006). Utility and limitations of species richness metrics for conservation planning. Ecological Indicators 6, 543-553.

Fortini, L., and Schubert, O. (2017). Beyond exposure, sensitivity and adaptive capacity: a response based ecological framework to assess species climate change vulnerability. Climate Change Responses 4, 2.

Fujimori, S., Hasegawa, T., Masui, T., Takahashi, K., Herran, D. S., Dai, H., Hijioka, Y., and Kainuma, M. (2017). SSP3: AIM implementation of Shared Socioeconomic Pathways. Global Environmental Change 42, 268-283.

Henwood, W. D. (2010). Toward a Strategy for the Conservation and Protection of the World's Temperate Grasslands. Great Plains Research: A Journal of Natural and Social Sciences 1074.

Hoekstra, J. M., Boucher, T. M., Ricketts, T. H., and Roberts, C. (2005). Confronting a biome crisis: global disparities of habitat loss and protection. Ecology Letters 8, 23-29.

Hoffmann, A. A., and Sgrò, C. M. (2011). Climate change and evolutionary adaptation. Nature 470, 479.

IIASA (2016). SSP Database (Shared Socioeconomic Pathways). (IIASA, ed.). 
INECC (2019). "Atlas of vulnerability to climate change in Mexico (Atlas de vulnerabilidad al cambio climático en México)." National Institute of Ecology and Climate Change. Instituto Nacional de Ecología y Cambio Climático (INECC), Mexico.

INEGI (1985). Conjunto de Datos Vectoriales de Uso del Suelo y Vegetación. Serie I. Instituto Nacional de Geografía y Estadística, Aguascalientes.

INEGI (1993). Conjunto de Datos Vectoriales de Uso de Suelo y Vegetación. Serie II. Instituto Nacional de Geografía y Estadística, Aguascalientes.

INEGI (2002). Conjunto de Datos Vectoriales de Uso de Suelo y Vegetación. Serie III. Instituto Nacional de Geografía y Estadística, Aguascalientes.

INEGI (2007). Conjunto de Datos Vectoriales de Uso del Suelo y Vegetación. Serie IV. Instituto Naciona de Geografía y Estadística, Aguascalientes.

INEGI (2011). Conjunto de Datos Vectoriales de Uso del Suelo y Vegetación. Serie V. Instituto Nacional de Geografía y Estadística, Aguascalientes.

INEGI (2015). Conjunto de Datos Vectoriales de Uso del Suelo y Vegetación (Serie V). pp. escala 1:250 000, serie V. INEGI, Aguascalientes.

IPBES (2019). "Global assessment report on biodiversity and ecosystem services of the Intergovernmental Science-Policy Platform on Biodiversity and Ecosystem Services." IPBES secretariat, Bonn, Germany.

IPCC (2014). Climate Change: Impacts, Adaptation, and Vulnerability. In "Part A: Global and Sectoral Aspects. Contribution of Working Group II to the Fifth Assessment Report of the Intergovernmental Panel on Climate Change (IPCC)." (C. Field, Barros V., K. Dokken and K. Mach, et al., , eds.), pp. 1132. IPCC, Cambridge, UN and New York, US.

IUCN (2014). "Towards a Conservation Strategy for the World's Temperate Grasslands." IUCN and WCPA, Vancouver, Canada.

IUCN (2017). The IUCN Red List of Threatened Species. Version 2017-3. .

Kara, A., Juan Manuel, D., Maria, G. G., Catherine, H., David, M., Camila, P., Beatriz, S.-N., Christina, M. S., Annette, T., Skip, J. V. B., Bonnie, G. W., Xiangtao, X., and Jennifer, S. P. (2017). Will seasonally dry tropical forests be sensitive or resistant to future changes in rainfall regimes? Environmental Research Letters 12, 023001.

Kc, S., and Lutz, W. (2017). The human core of the shared socioeconomic pathways: Population scenarios by age, sex and level of education for all countries to 2100. Global Environmental Change 42, 181-192.

Keinath, D. A., Doak, D. F., Hodges, K. E., Prugh, L. R., Fagan, W., Sekercioglu, C. H., Buchart, S. H. M., and Kauffman, M. (2017). A global analysis of traits predicting species sensitivity to habitat fragmentation. Global Ecology and Biogeography 26, 115-127.

Krupnick, G. A., and John Kress, W. (2003). Hotspots and ecoregions: a test of conservation priorities using taxonomic data. Biodiversity \& Conservation 12, 2237-2253.

Lambin, E. F., and Meyfroidt, P. (2011). Global land use change, economic globalization, and the looming land scarcity. Proceedings of the National Academy of Sciences 108, 3465-3472.

Linares-Palomino, R., Oliveira, A., and Pennington, T. (2011). Neotropical Seasonally Dry Forests: Diversity, Endemism, and Biogeography of Wood Plants. In "Seasonally Dry Tropical Forests. Ecology and Conservation." (R. Dirzo, H. S. Young, H. A. Mooney and G. Ceballos, eds.), pp. 3-21. Island Press.

Lindner, M., Maroschek, M., Netherer, S., Kremer, A., Barbati, A., Garcia-Gonzalo, J., Seidl, R., Delzon, S., Corona, P., Kolström, M., Lexer, M. J., and Marchetti, M. (2010). Climate change impacts, adaptive capacity, and vulnerability of European forest ecosystems. Forest Ecology and Management 259, 698-709.

Loyola, R. D., Kubota, U., and Lewinsohn, T. M. (2007). Endemic vertebrates are the most effective surrogates for identifying conservation priorities among Brazilian ecoregions. Diversity and Distributions 13, 389-396.

Margules, C. R., and Pressey, R. L. (2000). Systematic conservation planning. Nature 405, 243.

Mendoza-Ponce, A., Corona-Núñez, R., Kraxner, F., Leduc, S., and Patrizio, P. (2018). Identifying effects of land use cover changes and climate change on terrestrial ecosystems and carbon stocks in Mexico. Global Environmental Change 53, 12-23. 
Mittermeier, R., Robles, P., and Mittermeier, C. (1997). "Megadiversity: Earth’s Biologically Wealthiest Nations." CEMEX/ Agrupación Sierra Madre, Monterrey, Mexico.

Mittermeier, R., Turner, W., Larsen, F., Brooks, T., and Gascon, C. (2011a). Global Biodiversity Conservation: The Critical Role of Hotspots. In "Biodiversity Hotspots. Distribution and Protection of Conservation Priority Areas." (Z. Frank and H. Christian, eds.), pp. 3-22. Springer, Heidelberg, Dordrecht, London and New York.

Mittermeier, R., Turner, W., Larsen, F., Brooks, T., and Gascon, C. (2011b). Global Biodiversity Conservation: The Critical Role of Hotspots. In "Biodiversity Hotspots. Distributional and Protection of Conservation Priority Areas." (Z. Frank and H. Christian, eds.), pp. 3-22. Springer, London and New ork.

Monsarrat, S., Jarvie, S., and Svenning, J.-C. (2019). Anthropocene refugia: integrating history and predictive modelling to assess the space available for biodiversity in a human-dominated world. Philosophical transactions of the Royal Society of London. Series B, Biological sciences 374, 20190219.

Monterroso, A., and Conde, C. (2015). Exposure to climate and climate change in Mexico. Geomatics, Natural Hazards and Risk 6, 272-288.

Myers, N., Mittermeier, R. A., Mittermeier, C. G., da Fonseca, G. A. B., and Kent, J. (2000). Biodiversity hotspots for conservation priorities. Nature 403, 853.

Newbold, T., Hudson, L. N., Hill, S. L. L., Contu, S., Lysenko, I., Senior, R. A., Börger, L., Bennett, D. J., Choimes, A., Collen, B., Day, J., De Palma, A., Díaz, S., Echeverria-Londoño, S., Edgar, M. J., Feldman, A., Garon, M., Harrison, M. L. K., Alhusseini, T., Ingram, D. J., Itescu, Y., Kattge, J., Kemp, V., Kirkpatrick, L., Kleyer, M., Correia, D. L. P., Martin, C. D., Meiri, S., Novosolov, M., Pan, Y., Phillips, H. R. P., Purves, D. W., Robinson, A., Simpson, J., Tuck, S. L., Weiher, E., White, H. J., Ewers, R. M., Mace, G. M., Scharlemann, J. P. W., and Purvis, A. (2015). Global effects of land use on local terrestrial biodiversity. Nature 520, 45.

O’Neill, B. C., Kriegler, E., Ebi, K. L., Kemp-Benedict, E., Riahi, K., Rothman, D. S., van Ruijven, B. J., van Vuuren, D. P., Birkmann, J., Kok, K., Levy, M., and Solecki, W. (2017). The roads ahead: Narratives for shared socioeconomic pathways describing world futures in the $21 \mathrm{st}$ century. Global Environmental Change 42, 169-180.

Oliver, T. H., and Morecroft, M. D. (2014). Interactions between climate change and land use change on biodiversity: attribution problems, risks, and opportunities. Wiley Interdisciplinary Reviews: Climate Change 5, 317-335.

Pana, A. C., and Gheyssens, J. (2016). Baseline choice and performance implications for REDD. Journal of Environmental Economics and Policy 5, 79-124.

Paniw, M., James, T., Archer, C., Römer, G., Levin, S., Compagnoni, A., Che-Castaldo, J., Bennett, J., Mooney, A., Childs, D., Ozgul, A., Jones, O., Burns, J., Beckerman, A., Patwary, A., Sanchez-Gassen, N., Knight, T., and Salguero-Gómez, R. (2019). "Global analysis reveals complex demographic responses of mammals to climate change."

Popp, A., Calvin, K., Fujimori, S., Havlik, P., Humpenöder, F., Stehfest, E., Bodirsky, B. L., Dietrich, J. P., Doelmann, J. C., Gusti, M., Hasegawa, T., Kyle, P., Obersteiner, M., Tabeau, A., Takahashi, K., Valin, H., Waldhoff, S., Weindl, I., Wise, M., Kriegler, E., Lotze-Campen, H., Fricko, O., Riahi, K., and Vuuren, D. P. v. (2017). Land-use futures in the shared socioeconomic pathways. Global Environmental Change 42, 331-345.

Pressey, R. L., Johnson, I. R., and Wilson, P. D. (1994). Shades of irreplaceability: towards a measure of the contribution of sites to a reservation goal. Biodiversity \& Conservation 3, 242-262.

Prieto-Torres, D. A., Navarro-Sigüenza, A. G., Santiago-Alarcon, D., and Rojas-Soto, O. R. (2016). Response of the endangered tropical dry forests to climate change and the role of Mexican Protected Areas for their conservation. Global Change Biology 22, 364-379.

RAMSAR (2015). RAMSAR. Country profiles. Vol. 2020.

Riahi, K., van Vuuren, D. P., Kriegler, E., Edmonds, J., O’Neill, B. C., Fujimori, S., Bauer, N., Calvin, K., Dellink, R., Fricko, O., Lutz, W., Popp, A., Cuaresma, J. C., Kc, S., Leimbach, M., Jiang, L., Kram, T., Rao, S., Emmerling, J., Ebi, K., Hasegawa, T., Havlik, P., Humpenöder, F., Da Silva, L. A., Smith, S., Stehfest, E., Bosetti, V., Eom, J., Gernaat, D., Masui, T., Rogelj, J., Strefler, J., Drouet, L., Krey, V., Luderer, G., Harmsen, M., Takahashi, 
K., Baumstark, L., Doelman, J. C., Kainuma, M., Klimont, Z., Marangoni, G., Lotze-Campen, H., Obersteiner, M., Tabeau, A., and Tavoni, M. (2017). The Shared Socioeconomic Pathways and their energy, land use, and greenhouse gas emissions implications: An overview. Global Environmental Change 42, 153-168.

Rodríguez-Trejo, D., and Myers, R. (2010). Using Oak Characteristics to Guide Fire Regime Restoration in Mexican Pine-Oak and Oak Forests. Ecological Restoration 28, 304-323.

Rudel, T. K., Coomes, O. T., Moran, E., Achard, F., Angelsen, A., Xu, J., and Lambin, E. (2005). Forest transitions: towards a global understanding of land use change. Global Environmental Change 15, 23-31.

Sala, O. E., Stuart Chapin, F., Iii, Armesto, J. J., Berlow, E., Bloomfield, J., Dirzo, R., HuberSanwald, E., Huenneke, L. F., Jackson, R. B., Kinzig, A., Leemans, R., Lodge, D. M., Mooney, H. A., Oesterheld, M. n., Poff, N. L., Sykes, M. T., Walker, B. H., Walker, M., and Wall, D. H. (2000). Global Biodiversity Scenarios for the Year 2100. Science 287, 1770.

Soares-Filho, B., Rodrigues, H., and Costa, W. (2009). Modeling Environmental Dynamics with Dinamica EGO (Guidebook). (B. H. (IGC/UFMG) - Universidade Federal de Minas Gerais, MG, Brazil., ed.), pp. 115.

Stattersfield, A. J., Crosby, M. J., Long, A. J., and Wege, D. C. (1998). "Endemic Bird Areas of the World. Priorities for biodiversity conservation." BirdLife Conservation Series 7. Cambridge: BirdLife International.

Swab, R. M., Regan, H. M., Keith, D. A., Regan, T. J., and Ooi, M. K. J. (2012). Niche models tell half the story: spatial context and life-history traits influence species responses to global change. Journal of Biogeography 39, 1266-1277.

Tobón, W., Urquiza-Haas, T., Koleff, P., Schröter, M., Ortega-Álvarez, R., Campo, J., LindigCisneros, R., Sarukhán, J., and Bonn, A. (2017). Restoration planning to guide Aichi targets in a megadiverse country. Conservation Biology 31, 1086-1097.

UNEP-WCMC (2013). Centres of Plant Diversity. Version 1.0 (digital reproduction of Centres of Plant Diversity). (S. Davis, V. Heywood, H. A. C., WWf and IUCN, eds.), Gland, Switzerland.

Velázquez, A., Mas, J., Palacio, J., and Bocco, G. (2002). Land cover mapping to obtain a current profile of deforestation in Mexico. Unasylva 53, 37-40.

Watson, J. E. M., Dudley, N., Segan, D. B., and Hockings, M. (2014). The performance and potential of protected areas. Nature 515, 67.

Wilson, K., Cabeza, M., and Klein, C. (2009). Fundamental Concepts of Spatial Conservation Prioritization In "Spatial Conservation prioritization: Quantitative Methods and Computational Tools" (M. Atte, W. Kerrie and P. Hugh, eds.), pp. 16-27. Oxford University press, Oxford, UK.

Williams, S. E., Shoo, L. P., Isaac, J. L., Hoffmann, A. A., and Langham, G. (2008). Towards an Integrated Framework for Assessing the Vulnerability of Species to Climate Change. PLOS Biology 6, e325. 


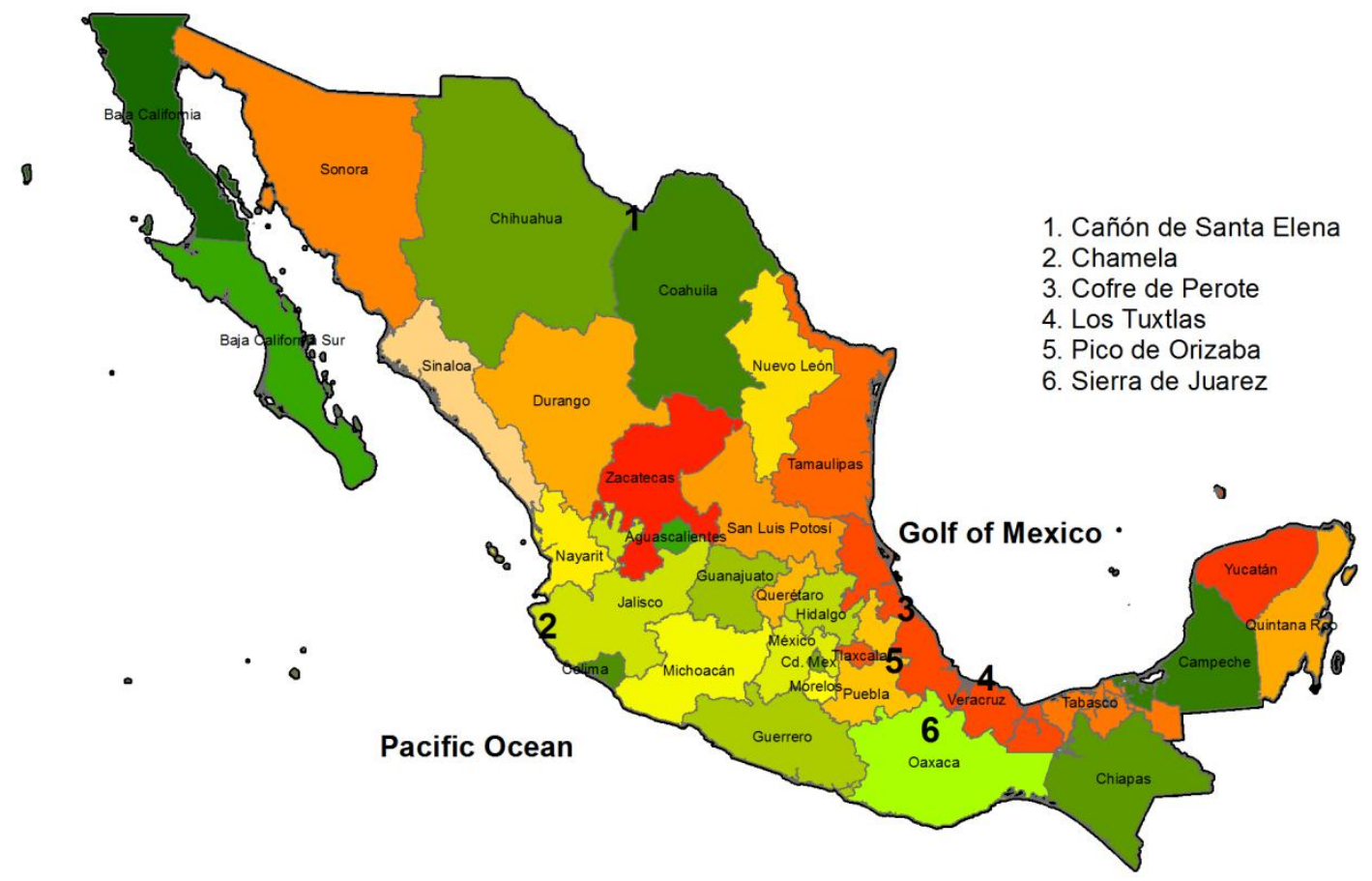

Fig A.1. Mexican States. The numbers represent the location of physiographic and biogeographic regions.

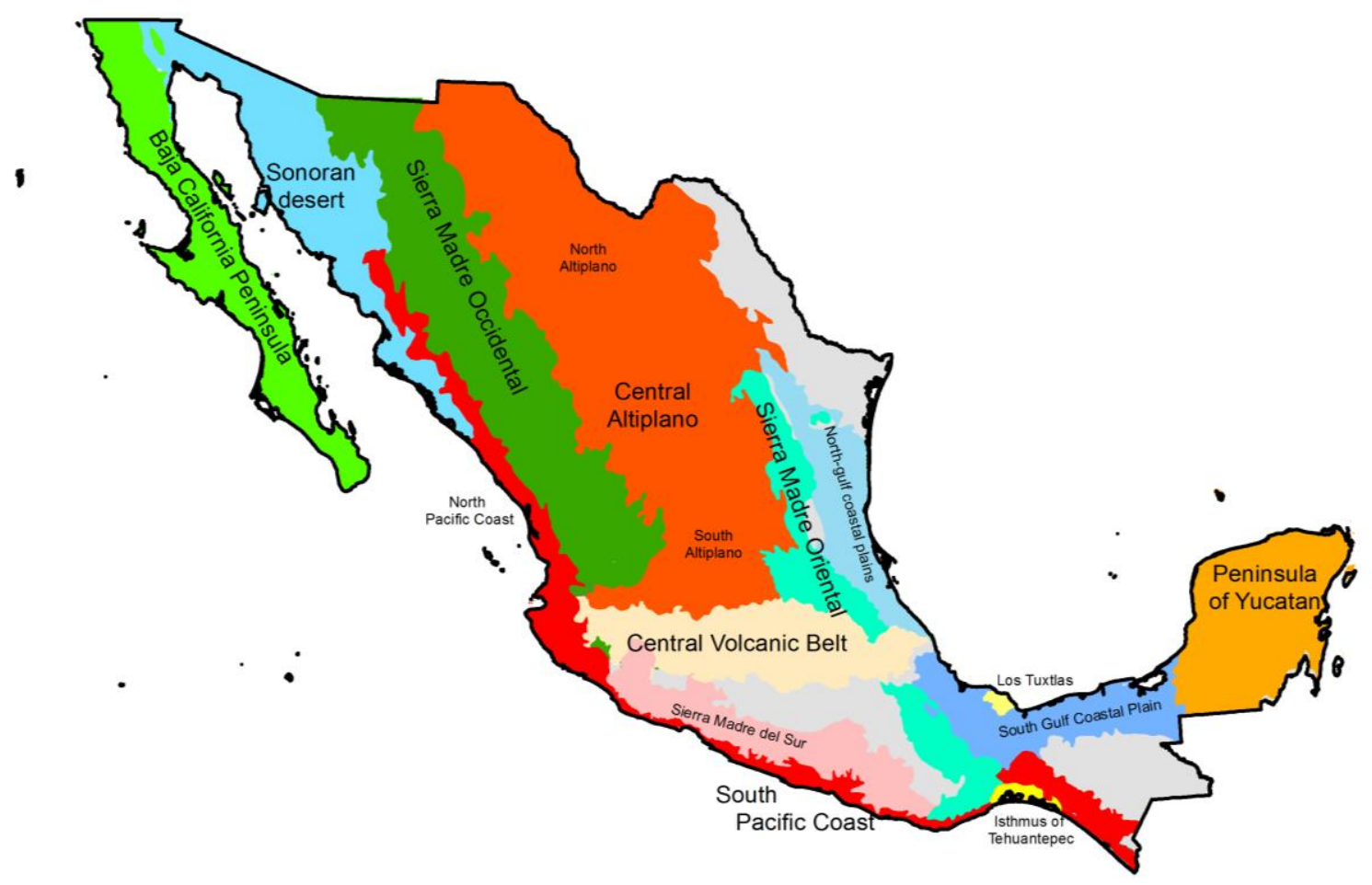

Fig A.2. Physiographic regions of Mexico reported in the manuscript. 


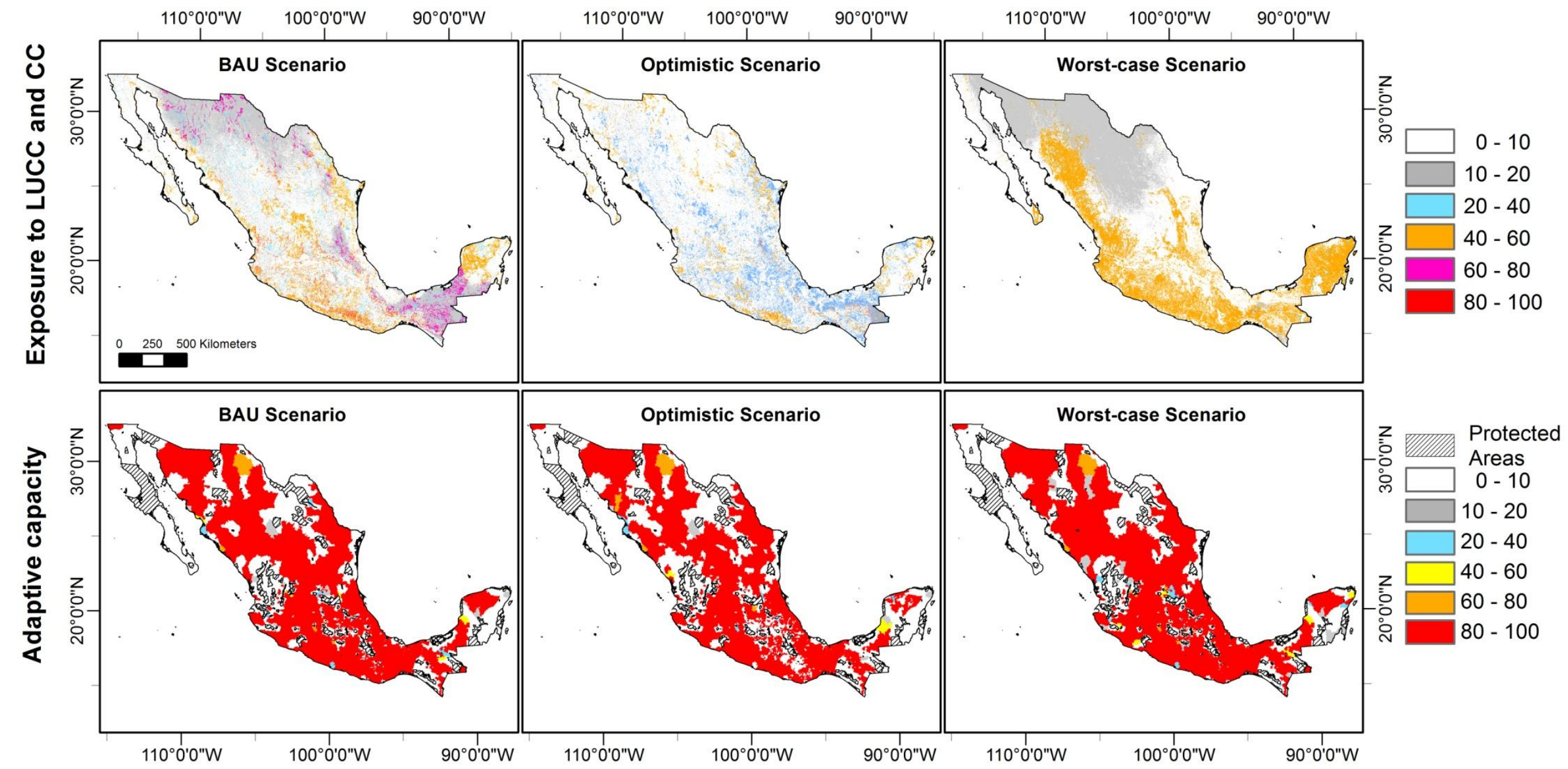

Fig. A.3. Exposure and adaptive capacity by 2070 for the business-as-usual (BAU), optimistic and worst-case scenarios for Mexico. All the data are normalized between 0 and 100 (see methods). LUCC refers to land-use/cover-change and CC to climate change. 


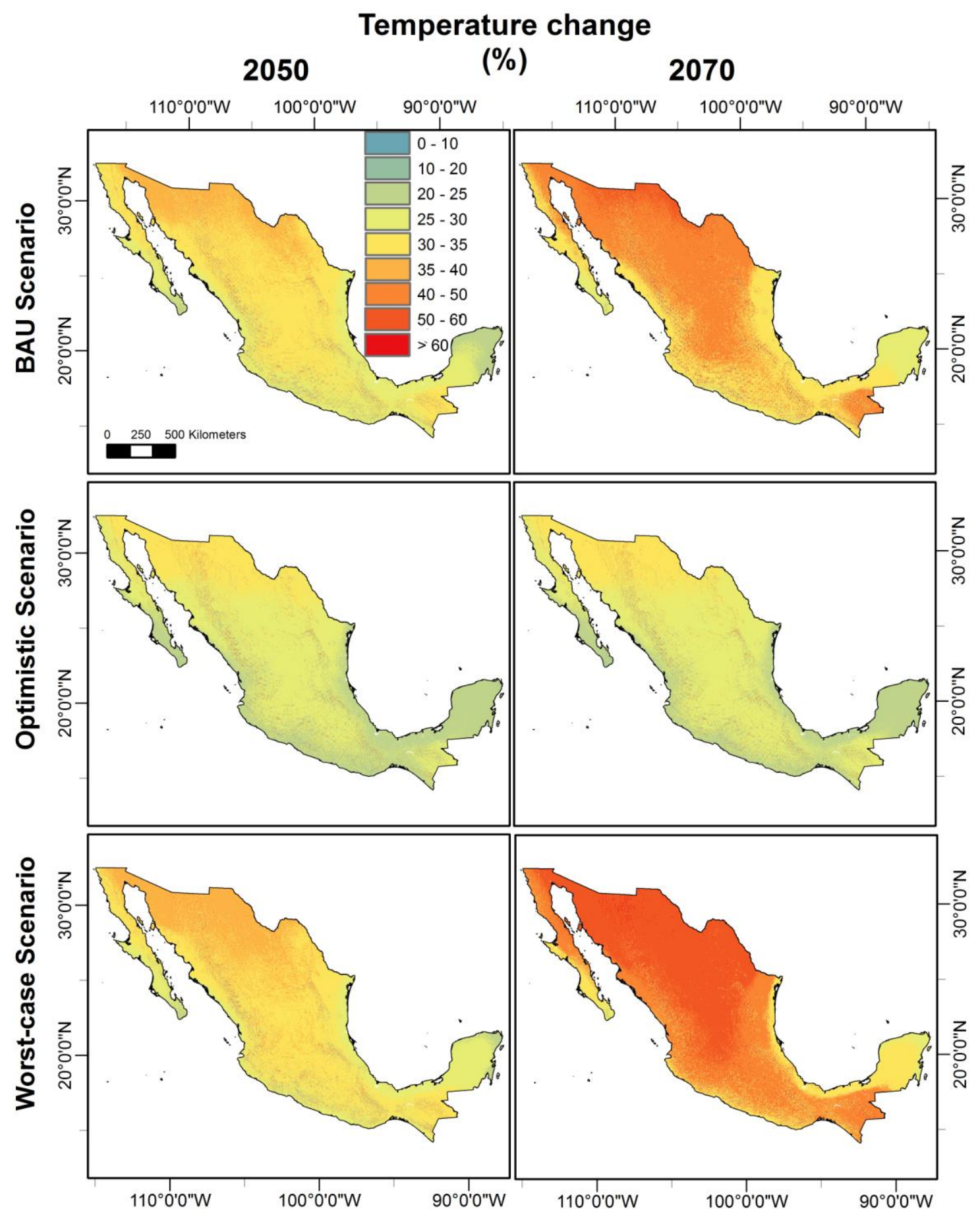

Fig. A.4. Change of mean annual temperature in percentage (\%) for the 2050 and 2070 for the business-as-usual (BAU), optimistic and worst-case scenarios for Mexico. 


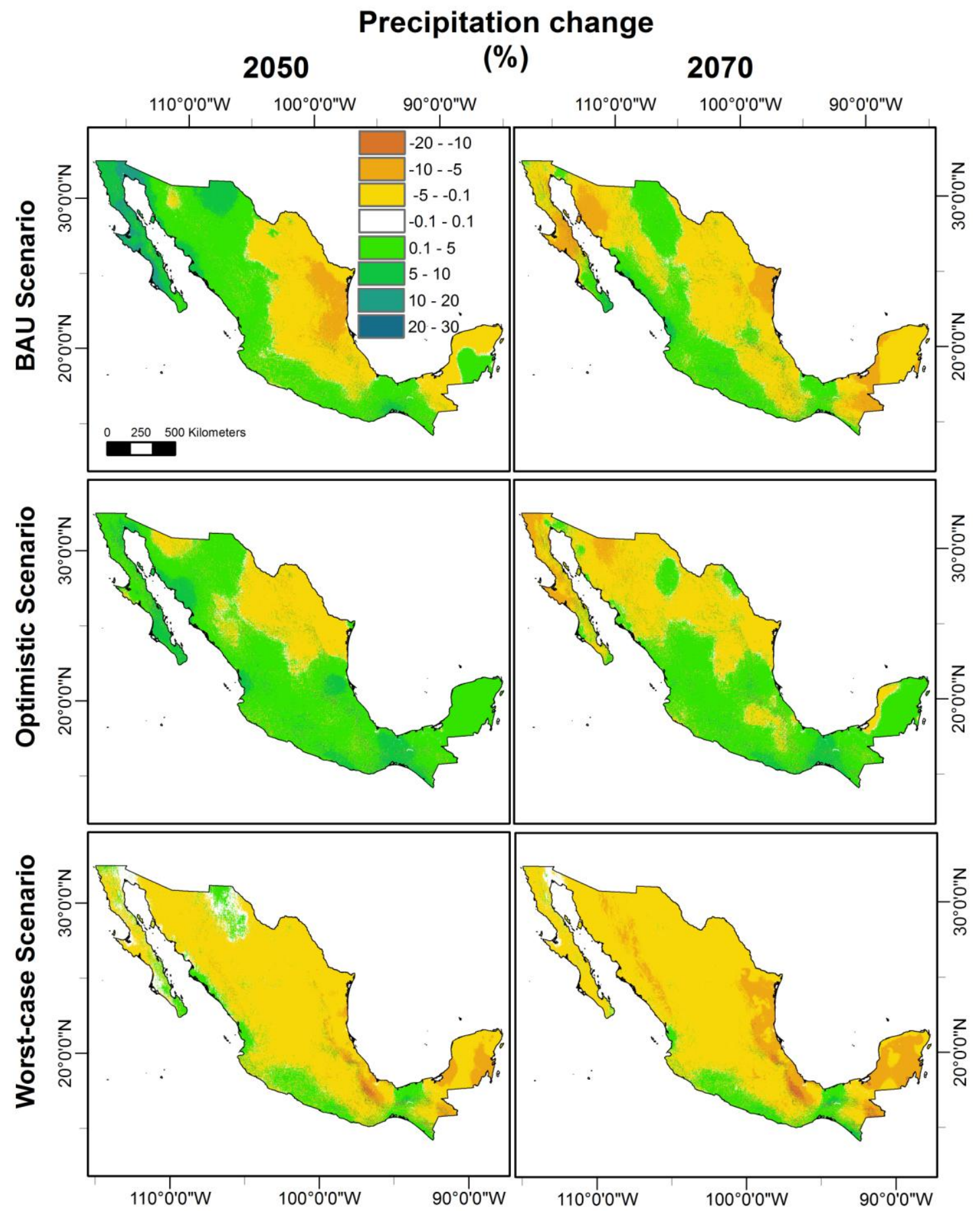

Fig. A.5. Change of annual precipitation in percentage (\%) for the 2050 and 2070 for the business-as-usual (BAU), optimistic and worst-case scenarios for Mexico. 


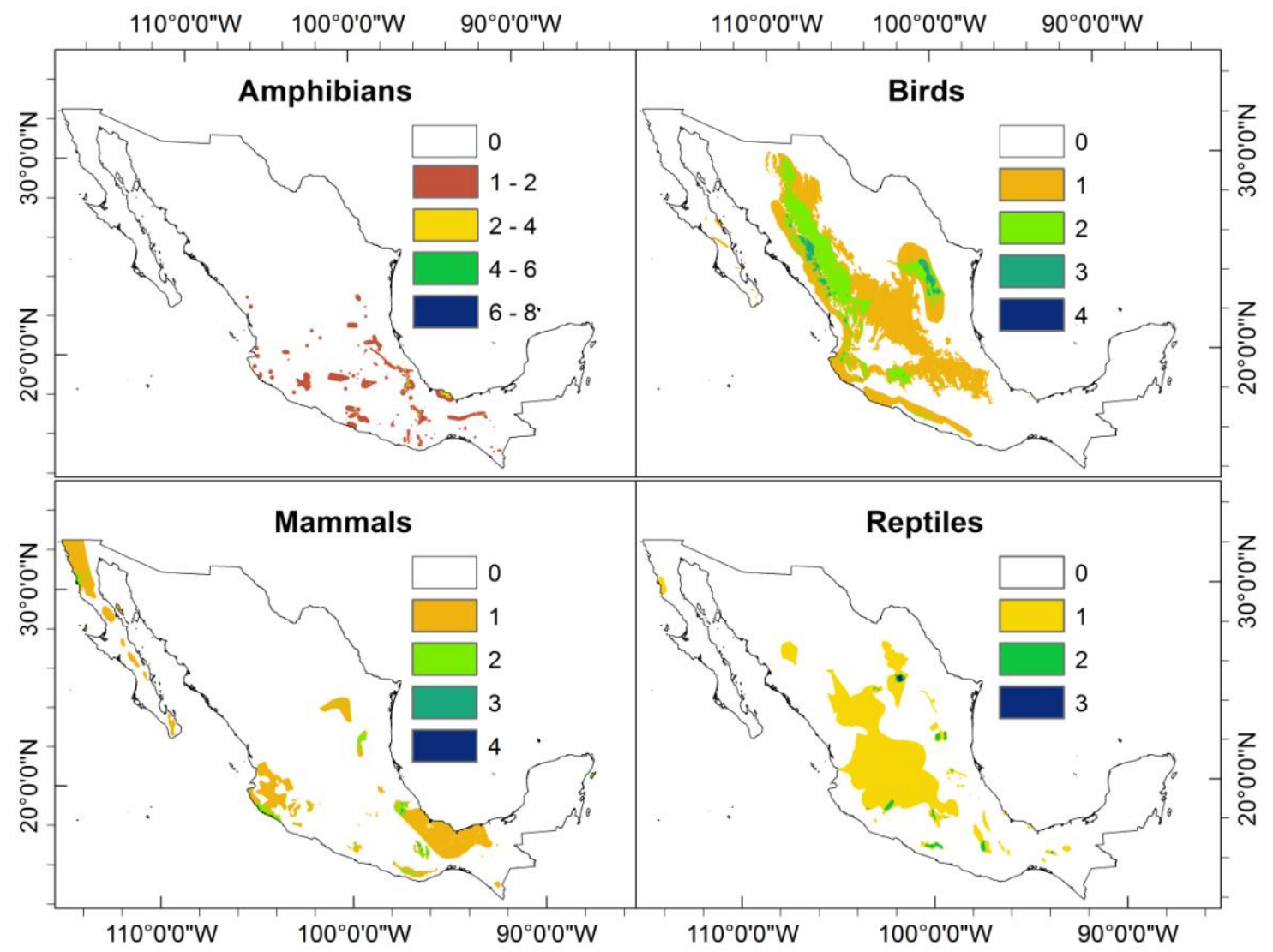

Fig. A.6. Number of species per vertebrate groups. 
Table A.1. Explanatory variables used in the LUCC model.

\begin{tabular}{|c|c|c|c|c|c|}
\hline \multicolumn{3}{|c|}{ Socioeconomic } & \multicolumn{3}{|l|}{ Biophysical } \\
\hline Variable and units & $\begin{array}{l}\text { Spatial } \\
\text { resolution }\end{array}$ & Source & Variable and units & $\begin{array}{c}\text { Spatial } \\
\text { resolution }\end{array}$ & Source \\
\hline $\begin{array}{l}\text { 1.Population (number of people) } \\
\text { 2.Population density (people } \mathrm{km}^{2}{ }^{2} \text { ) }\end{array}$ & Municipality & $\begin{array}{l}\text { (INEGI, } \\
\text { 1980, 1985, } \\
\text { 1990, 1995, } \\
\text { 2000a, 2005, } \\
\text { 2010a) } \\
\text { (IIASA, } \\
\text { 2016) }\end{array}$ & 14. Digital Elevation Model (DEM) (masl) & $60 \mathrm{~m}$ & (INEGI, 2013) \\
\hline $\begin{array}{l}\text { 3. GDP (billion US PP } \$ 2005 \mathrm{yr}^{-1} \text { ) } \\
\text { 4.GDP per capita }\end{array}$ & Municipality & $\begin{array}{l}\text { (IIASA, } \\
2016) \\
\text { (SNIM, } \\
2005)\end{array}$ & 15. Slope (degrees) & $60 \mathrm{~m}$ & $\begin{array}{l}\text { Derived from } \\
\text { the DEM }\end{array}$ \\
\hline 5.Index of marginalization & Municipality & $\begin{array}{l}\text { (CONAPO, } \\
2010)\end{array}$ & 16.Distance to rivers (m) & $1: 400,000$ & $\begin{array}{l}\text { (Maderey-R. } \\
\text { and Torres- } \\
\text { Ruata, 1990) }\end{array}$ \\
\hline $\begin{array}{l}\text { 6. Volume of agricultural products (ton) } \\
\text { 7. Volume of wood products }\left(\mathrm{m}^{3}\right) \\
\text { 8. Value of agricultural products (million } \\
\text { Mexican pesos) } \\
\text { 9. Value of wood products (million } \\
\text { Mexican pesos) }\end{array}$ & Municipality & $\begin{array}{l}\text { (INEGI, } \\
\text { 2011) }\end{array}$ & 17. Soil types & $1: 250,000$ & $\begin{array}{l}\text { (INEGI, } \\
\text { 2014a) }\end{array}$ \\
\hline 10. Distance to roads (m) & $1: 250,000$ & (SCT, 2008) & \multirow{4}{*}{$\begin{array}{l}\text { 18. Annual Mean Temperature }(\mathrm{BIO} 1)\left({ }^{\circ} \mathrm{C}\right) \\
\text { 19. Temperature Seasonality (BIO4) }\left({ }^{\circ} \mathrm{C}\right) \\
\text { 20. Maximum Temperature of Warmest Month (BIO5) }\left({ }^{\circ} \mathrm{C}\right) \\
\text { 21. Temperature Annual Range (BIO7) }\left({ }^{\circ} \mathrm{C}\right) \\
\text { 22. Mean Temperature of Wettest Quarter }(\mathrm{BIO})\left({ }^{\circ} \mathrm{C}\right) \\
\text { 23. Mean Temperature of Warmest Quarter }(\mathrm{BIO} 10)\left({ }^{\circ} \mathrm{C}\right) \\
\text { 24. Annual Precipitation (BIO12) }(\mathrm{mm})\end{array}$} & \multirow[t]{4}{*}{$\sim 1 \mathrm{~km}^{2}$} & \multirow{4}{*}{$\begin{array}{l}\text { (Fick and } \\
\text { Hijmans, } \\
2017 \text { ) }\end{array}$} \\
\hline 11. Distance to highways (m) & $1: 250,000$ & $\begin{array}{l}\text { (INEGI, } \\
2014 \mathrm{~b})\end{array}$ & & & \\
\hline $\begin{array}{l}\text { 12. Distance to localities and to urban } \\
\text { areas }(\mathrm{m})\end{array}$ & $1: 250,000$ & $\begin{array}{l}\text { (INEGI, } \\
2000 \mathrm{~b}, \\
2010 \mathrm{~b} \text { ) }\end{array}$ & & & \\
\hline $\begin{array}{l}\text { 13. Protected Areas and distance to PA } \\
(\mathrm{m})\end{array}$ & $1: 50,000$ & $\begin{array}{l}\text { (CONANP, } \\
2015,2016)\end{array}$ & & & \\
\hline
\end{tabular}


Table A.2. Historical rates of change for Mexico.

\begin{tabular}{rccccc}
\hline $\mathbf{T}_{\mathbf{0}}$ & $\mathbf{T}_{\mathbf{1}}$ & $\mathbf{A}_{\mathbf{0}}$ & $\mathbf{A}_{\mathbf{1}}$ & \multicolumn{2}{c}{ Rates of change } \\
& & & & $\mathbf{k m}^{\mathbf{2}} \mathbf{y r}^{-\mathbf{1}} \mathbf{\text { 0-T1 }}$ & $\mathbf{\%} \mathbf{~} \mathbf{r}^{-\mathbf{1}} \mathbf{\text { T0-T1}}$ \\
\hline 1985 & 1993 & $1,505,558$ & $1,430,733$ & 9,353 & -0.64 \\
1985 & 2002 & $1,505,558$ & $1,401,709$ & 6,109 & -0.42 \\
1985 & 2007 & $1,505,558$ & $1,382,465$ & 5,595 & -0.39 \\
1985 & 2011 & $1,505,558$ & $1,374,869$ & 5,026 & -0.35 \\
1993 & 2002 & $1,430,733$ & $1,401,709$ & 3,225 & -0.23 \\
$* * * 1993$ & 2007 & $1,430,733$ & $1,382,465$ & 3,448 & -0.24 \\
1993 & 2011 & $1,430,733$ & $1,374,869$ & 3,104 & -0.22 \\
2002 & 2007 & $1,401,709$ & $1,382,465$ & 3,849 & -0.28 \\
2002 & 2011 & $1,401,709$ & $1,374,869$ & 2,982 & -0.21 \\
2007 & 2011 & $1,382,465$ & $1,374,869$ & 1,899 & -0.14 \\
\hline
\end{tabular}

$\boldsymbol{T}$ refers to the time step. $\boldsymbol{A}$ expresses the total area in $\mathrm{km}^{2}$ for specific $T$. The rates of change are expressed in area and percentage on an annual basis for a specific time frame. **Highlights the selected period to model BAU scenario. 
TableA.3. Annual rates of change per land use and land cover $\left(\% \mathrm{yr}^{-1}\right)$. In colors are highlighted the lowest deforestation (gray) and the highest regeneration (green) rates. The optimistic scenario matrix was built from the lowest deforestation and highest regeneration rates. The worst-case scenario considers the highest rates of loss (orange) and the closest the mean of the regeneration rates (blue). There is no regeneration from irrigated agriculture nor urban covers. The national land use cover map from 2015 (INEGI)was used for validation.

\begin{tabular}{|c|c|c|c|c|c|c|c|c|c|c|}
\hline & $\begin{array}{c}\text { Temperate } \\
\text { forests }\end{array}$ & Cloud forests & Hydrophilic & Scrublands & $\begin{array}{c}\text { Tropical } \\
\text { evergreen } \\
\text { forests }\end{array}$ & $\begin{array}{l}\text { Tropical dry } \\
\text { forests }\end{array}$ & $\begin{array}{c}\text { Natural } \\
\text { grasslands }\end{array}$ & $\begin{array}{c}\text { Other } \\
\text { vegetation }\end{array}$ & Pasture & $\begin{array}{c}\text { Rainfed } \\
\text { agriculture }\end{array}$ \\
\hline & \multicolumn{8}{|c|}{ Rates of vegetation loss } & \multicolumn{2}{|c|}{ Rates of regeneration } \\
\hline $1985-1993$ & 0.596 & 1.235 & 1.772 & 0.852 & 1.858 & 1.575 & 6.998 & 0.726 & 4.655 & 1.682 \\
\hline 1985-2002 & 0.437 & 0.790 & 0.999 & 0.497 & 1.225 & 1.099 & 0.394 & 0.458 & 0.789 & 0.690 \\
\hline 1985-2007 & 0.369 & 0.633 & 0.797 & 0.446 & 1.078 & 0.982 & 0.390 & 0.439 & 0.671 & 0.540 \\
\hline 1985-2011 & 0.330 & 0.561 & 0.691 & 0.401 & 0.928 & 0.906 & 0.352 & 0.368 & 0.512 & 0.477 \\
\hline 1993-2002 & 0.356 & 0.566 & 0.621 & 0.211 & 1.047 & 0.766 & 5.329 & 0.320 & 4.236 & 0.426 \\
\hline 1993-2007 & 0.368 & 0.513 & 0.631 & 0.267 & 1.017 & 0.892 & 3.365 & 0.409 & 2.814 & 0.609 \\
\hline 1993-2011 & 0.309 & 0.419 & 0.522 & 0.243 & 0.834 & 0.810 & 2.633 & 0.316 & 2.200 & 0.510 \\
\hline 2002-2007 & 0.553 & 0.544 & 0.822 & 0.406 & 1.338 & 1.441 & 0.924 & 0.670 & 1.552 & 1.311 \\
\hline $2002-2011$ & 0.361 & 0.368 & 0.572 & 0.307 & 0.923 & 1.068 & 0.626 & 0.381 & 1.047 & 0.843 \\
\hline 2007-2011 & 1.388 & 1.889 & 2.348 & 1.089 & 3.753 & 3.602 & 11.796 & 1.417 & 9.965 & 2.314 \\
\hline
\end{tabular}


Table A.4. List of endemic and critically endangered or endangered terrestrial vertebrates in México.

\section{Count Amphibians}

1 Ambystoma flavipiperatum

2 Craugastor omiltemanus

3 Craugastor polymniae

4 Craugastor pozo

5 Ambystoma granulosum

6 Craugastor silvicola

7 Craugastor spatulatus

8 Craugastor uno

9 Craugastor vulcani

10 Cryptotriton alvarezdeltoroi

11 Ambystoma leorae

12 Duellmanohyla chamulae

13 Ambystoma lermaense

14 Duellmanohyla ignicolor

15 Ecnomiohyla echinata

16 Ecnomiohyla valancifer

17 Eleutherodactylus dennisi

18 Eleutherodactylus dilatus

19 Eleutherodactylus dixoni

20 Eleutherodactylus grandis

21 Ambystoma mexicanum

22 Eleutherodactylus rufescens

23 Eleutherodactylus saxatilis

24 Eleutherodactylus syristes

25 Ambystoma ordinarium

26 Exerodonta chimalapa

\section{Birds}

Xenospiza baileyi

Zentrygon carrikeri

Campephilus imperialis

Geothlypis beldingi

Geothlypis speciosa

Amazona finschi

Hydrobates macrodactylus

Lophornis brachylophus

Rhynchopsitta pachyrhyncha

Rhynchopsitta terrisi

Spizella wortheni

Toxostoma guttatum

\section{Mammals}

Geomys tropicalis

Habromys chinanteco

Habromys delicatulus

Habromys ixtlani

Habromys lepturus

Habromys schmidlyi

Habromys simulatus

Dipodomys gravipes

Lepus flavigularis

Megadontomys cryophilus

Megadontomys nelsoni

Megadontomys thomasi

Microtus oaxacensis

Microtus umbrosus

Myotis peninsularis

Myotis planiceps

Nelsonia goldmani

Neotoma angustapalata

Neotoma bryanti

Neotoma nelsoni

Orthogeomys lanius

Otospermophilus beecheyi

Pappogeomys bulleri

Peromyscus bullatus

Peromyscus caniceps

Peromyscus guardia

\section{Reptiles}

Barisia herrerae

Barisia rudicollis

Chersodromus rubriventris

Crotalus pusillus

Abronia chiszari

Crotaphytus antiquus

Ficimia hardyi

Gerrhonotus parvus

Abronia deppii

Lepidophyma lipetzi

Anniella geronimensis

Mesaspis juarezi

Mixcoatlus barbouri

Mixcoatlus melanurus

Ophisaurus ceroni

Abronia fuscolabialis

Anolis breedlovei

Rhadinaea marcellae

Rhadinaea montana

Abronia graminea

Sceloporus chaneyi

Sceloporus cyanostictus

Sceloporus exsul

Anolis hobartsmithi

Tantilla flavilineata

Tantilla shawi 
27 Incilius cavifrons

28 Incilius cristatus

29 Incilius gemmifer

30 Incilius perplexus

31 Ambystoma taylori

32 Incilius spiculatus

33 Isthmura gigantea

34 Isthmura maxima

35 Isthmura naucampatepetI

36 Ixalotriton niger

37 Ixalotriton parvus

38 Lithobates chichicuahutla

39 Lithobates dunni

40 Lithobates johni

41 Lithobates omiltemanus

42 Lithobates pueblae

43 Lithobates tlaloci

44 Megastomatohyla mixe

45 Megastomatohyla mixomaculata

46 Megastomatohyla nubicola

47 Megastomatohyla pellita

48 Parvimolge townsendi

49 Plectrohyla arborescandens

50 Plectrohyla calthula

51 Plectrohyla calvicollina

52 Plectrohyla celata

53 Plectrohyla cembra

54 Plectrohyla charadricola
Peromyscus interparietalis

Peromyscus mekisturus

Peromyscus melanocarpus

Peromyscus melanurus

Peromyscus ochraventer

Peromyscus pseudocrinitus

Peromyscus sejugis

Peromyscus stephani

Peromyscus winkelmanni

Procyon pygmaeus

Reithrodontomys bakeri

Reithrodontomys spectabilis

Rheomys mexicanus

Rhogeessa genowaysi

Romerolagus diazi

Sigmodon planifrons

Sorex sclateri

Sorex stizodon

Sylvilagus insonus

Sylvilagus mansuetus

Tamiasciurus mearnsi

Tylomys bullaris

Tylomys tumbalensis

Xenomys nelsoni

Xerospermophilus

perotensis

Zygogeomys trichopus

Heteromys spectabilis

Cryptotis nelsoni
Anolis pygmaeus

Thamnophis melanogaster

Thamnophis mendax

Trachemys taylori

Uma exsul

Xenosaurus newmanorum

Xenosaurus platyceps

Abronia martindelcampoi 
55 Plectrohyla chryses

56 Plectrohyla crassa

57 Plectrohyla cyanomma

58 Plectrohyla cyclada

59 Plectrohyla ephemera

60 Plectrohyla hazelae

61 Plectrohyla lacertosa

62 Plectrohyla mykter

63 Plectrohyla pachyderma

64 Plectrohyla pentheter

65 Plectrohyla psarosema

66 Plectrohyla pycnochila

67 Plectrohyla robertsorum

68 Plectrohyla sabrina

69 Plectrohyla siopela

70 Plectrohyla thorectes

71 Pseudoeurycea ahuitzotl

72 Pseudoeurycea altamontana

73 Pseudoeurycea anitae

74 Pseudoeurycea aquatica

75 Pseudoeurycea aurantia

76 Pseudoeurycea conanti

77 Pseudoeurycea firscheini

78 Pseudoeurycea goebeli

79 Pseudoeurycea juarezi

80 Pseudoeurycea lineola

81 Pseudoeurycea longicauda

82 Pseudoeurycea lynchi

83 Pseudoeurycea melanomolga
Cynomys mexicanus

Dasyprocta mexicana 
84 Pseudoeurycea mystax

85 Pseudoeurycea nigromaculata

86 Pseudoeurycea obesa

87 Pseudoeurycea orchileucos

88 Pseudoeurycea orchimelas

89 Pseudoeurycea papenfussi

90 Pseudoeurycea robertsi

91 Pseudoeurycea ruficauda

92 Pseudoeurycea saltator

93 Pseudoeurycea smithi

94 Pseudoeurycea tenchalli

95 Pseudoeurycea teotepec

96 Pseudoeurycea tlahcuiloh

97 Pseudoeurycea tlilicxit/

98 Pseudoeurycea unguidentis

99 Pseudoeurycea werleri

100 Ptychohyla erythromma

101 Ptychohyla leonhardschultzei

102 Smilisca dentata

103 Thorius adelos

104 Thorius arboreus

105 Thorius aureus

106 Thorius boreas

107 Thorius dubitus

108 Thorius grandis

109 Thorius infernalis

110 Thorius insperatus

111 Thorius lunaris

112 Thorius magnipes 
113 Thorius minutissimus

114 Thorius minydemus

115 Thorius munificus

116 Thorius narismagnus

117 Thorius narisovalis

118 Thorius omiltemi

119 Thorius papaloae

120 Thorius pennatulus

121 Thorius pulmonaris

122 Thorius schmidti

123 Thorius smithi

124 Thorius spilogaster

125 Thorius troglodytes

126 Aquiloeurycea praecellens

127 Aquiloeurycea quetzalanensis

128 Ambystoma altamirani

129 Bolitoglossa riletti

130 Ambystoma amblycephalum

131 Bolitoglossa veracrucis

132 Bolitoglossa zapoteca

133 Bromeliohyla dendroscarta

134 Charadrahyla altipotens

135 Charadrahyla chaneque

136 Charadrahyla trux

137 Ambystoma andersoni

138 Chiropterotriton arboreus

139 Chiropterotriton chiropterus

140 Chiropterotriton chondrostega

141 Chiropterotriton cracens 


\author{
142 Chiropterotriton dimidiatus \\ 143 Chiropterotriton lavae \\ 144 Chiropterotriton magnipes \\ 145 Chiropterotriton mosaueri \\ 146 Chiropterotriton multidentatus \\ 147 Ambystoma bombypellum \\ 148 Chiropterotriton terrestris \\ 149 Craugastor glaucus \\ 150 Ambystoma dumerilii \\ 151 Craugastor guerreroensis \\ 152 Craugastor hobartsmithi \\ 153 Craugastor megalotympanum \\ 154 Craugastor montanus
}

\title{
References
}

CONANP, 2015. Áreas Naturales Protegidas estatales, municipales y privadas de México. Comisión Nacional de Áreas Naturales Protegidas. CONANP, 2016. Áreas Natural Protegidas Federales de México. Comisión Nacional de Áreas Naturales Protegidas.
CONAPO
2010.
Indice
de marginación
1995,
2000,
2005
\& 2010.
Consejo
Nacional
de Población

p.

Fick, S.E., Hijmans, R.J., 2017. WorldClim 2: new 1-km spatial resolution climate surfaces for global land areas. International Journal of Climatology, n/a-n/a.

IIASA, 2016. SSPS Database (Shared Socioeconomic Pathways) version 1.1. International institute for Applied Systems Analysis (IIASA).

https://tntcat.iiasa.ac.at/SspDb. Accessed 12th February 2017.

INEGI, 1980. Censo de Población y Vivienda 1980. In: Estadística, I.N.d.G.y. (Ed.).

INEGI, 1985. Conteo de Población y Vivienda 1985. In: Estadística, I.N.d.G.y. (Ed.).

INEGI (Ed), 1990. Censo de Población y Vivienda 1990. Instituto Nacional de Geografía y Estadística.

INEGI, 1995. Conteo de Población y Vivienda 1995. In: Estadística, I.N.e.G.y. (Ed.).

INEGI, 2000a. Censo de Población y Vivienda 2000. In: Estadística, I.N.d.G.y. (Ed.). 
INEGI, 2000b. Localidades de la República Mexicana, 2000. Instituto Nacional de Geografía y Estadística.

INEGI, 2005. Conteo de Población y Vivienda 2005. In: Estadística, I.N.d.G.y. (Ed.).

INEGI, 2010a. Censo de Población y Vivienda 2010. In: Estadística, I.N.d.G.y. (Ed.).

INEGI, 2010b. Mapa de localidades y poblaciones de México. Instituto Nacional de geografía y Estadística.

INEGI, 2011. Censo agrícola, ganadero y forestal. In: Estadística, I.N.d.G.y. (Ed.).

INEGI, 2013. Continuo de Elevaciones de México 3.0 (CEM 3.0). Instituto Nacional de Geografía y Estadística.

INEGI, 2014a. Conjunto de datos vectoriales edafológicos (Continuo Nacional). Instituto Nacional de Geografía y Estadística.

INEGI, 2014b. Red Vial. Red Nacional de Caminos (RNC). Instituto Nacional de Geografía y Estadística.

INEGI, 2015. Conjunto de Datos Vectoriales de Uso del Suelo y Vegetación. Serie VI. Instituto Nacional de Geografía y Estadística, Aguascalientes.

Maderey-R., Torres-Ruata, C., 1990. Hidrología, ríos y corrientes de agua. Instituo Nacional de Geografía UNAM.

SCT, 2008. Red de vías de comunicación. Secretaría de Comunicaciones y Transportes.

SNIM, 2005. Producto Interno Bruto Municipal 2005. In: Municipal, S.N.d.I. (Ed.). 


\section{Acknowledgments:}

The authors are gratefully for the DGAPA postdoctoral fellowships. Also we want to acknowledge the English editing of Alan Freeman. 


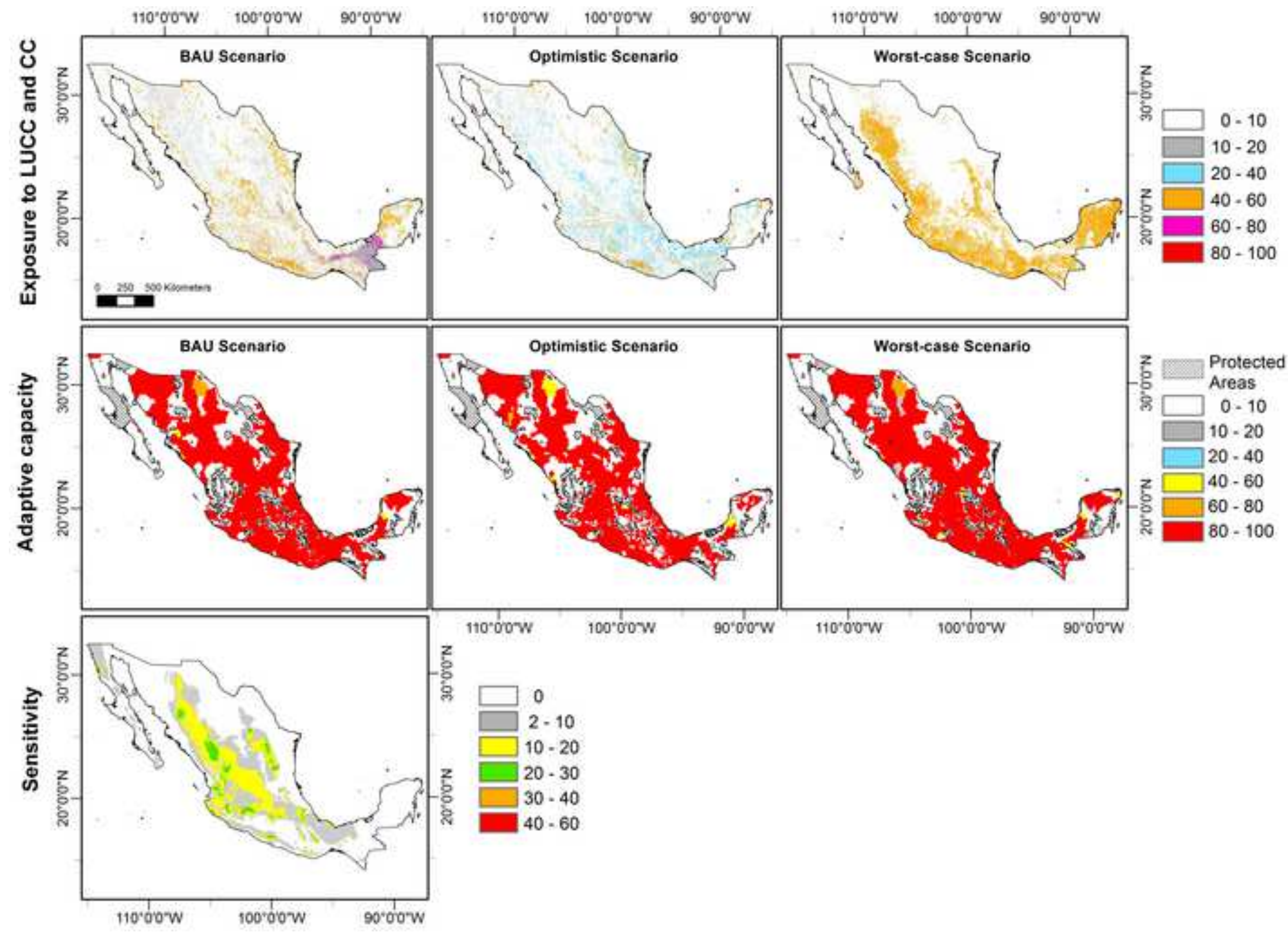




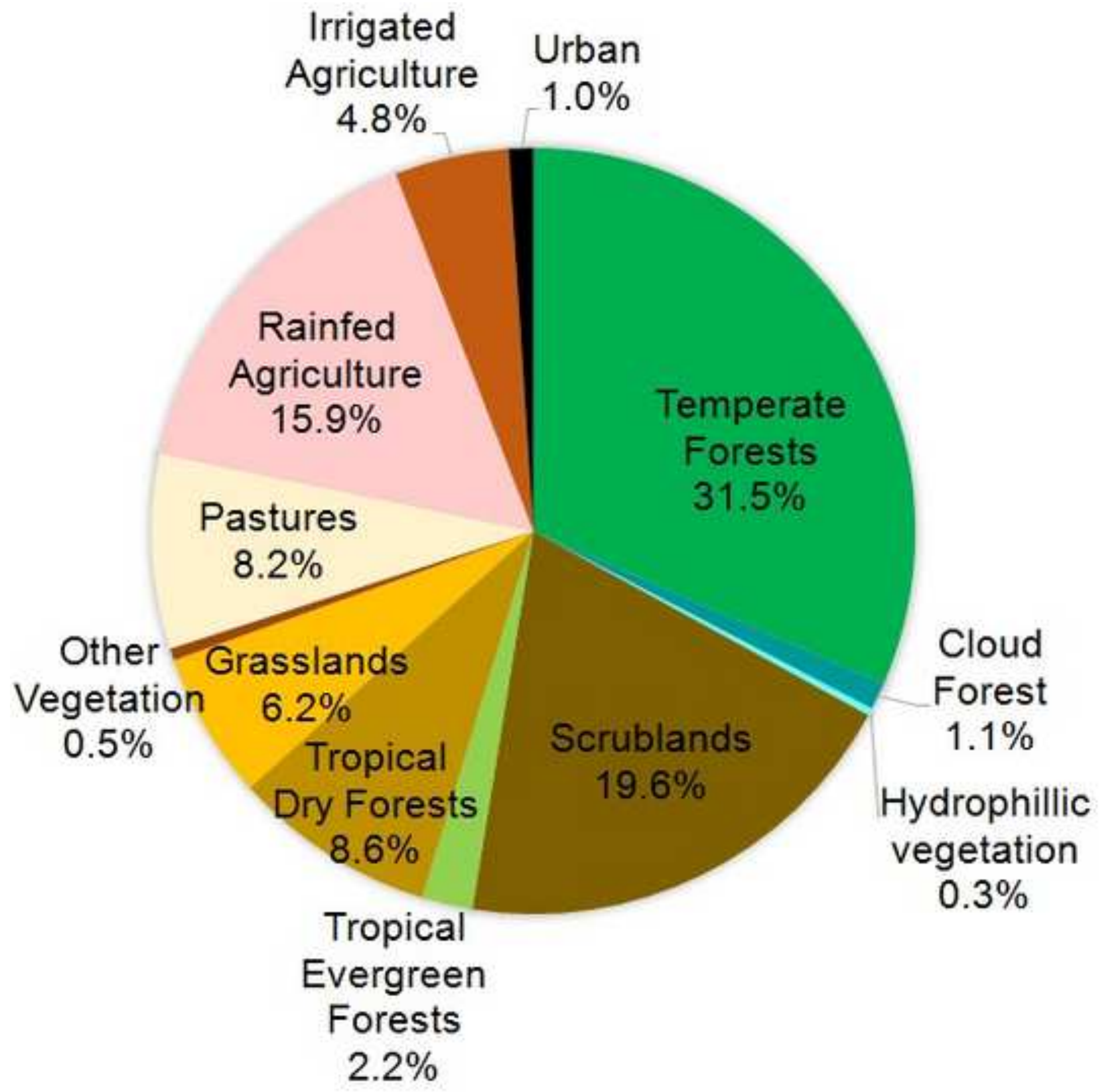




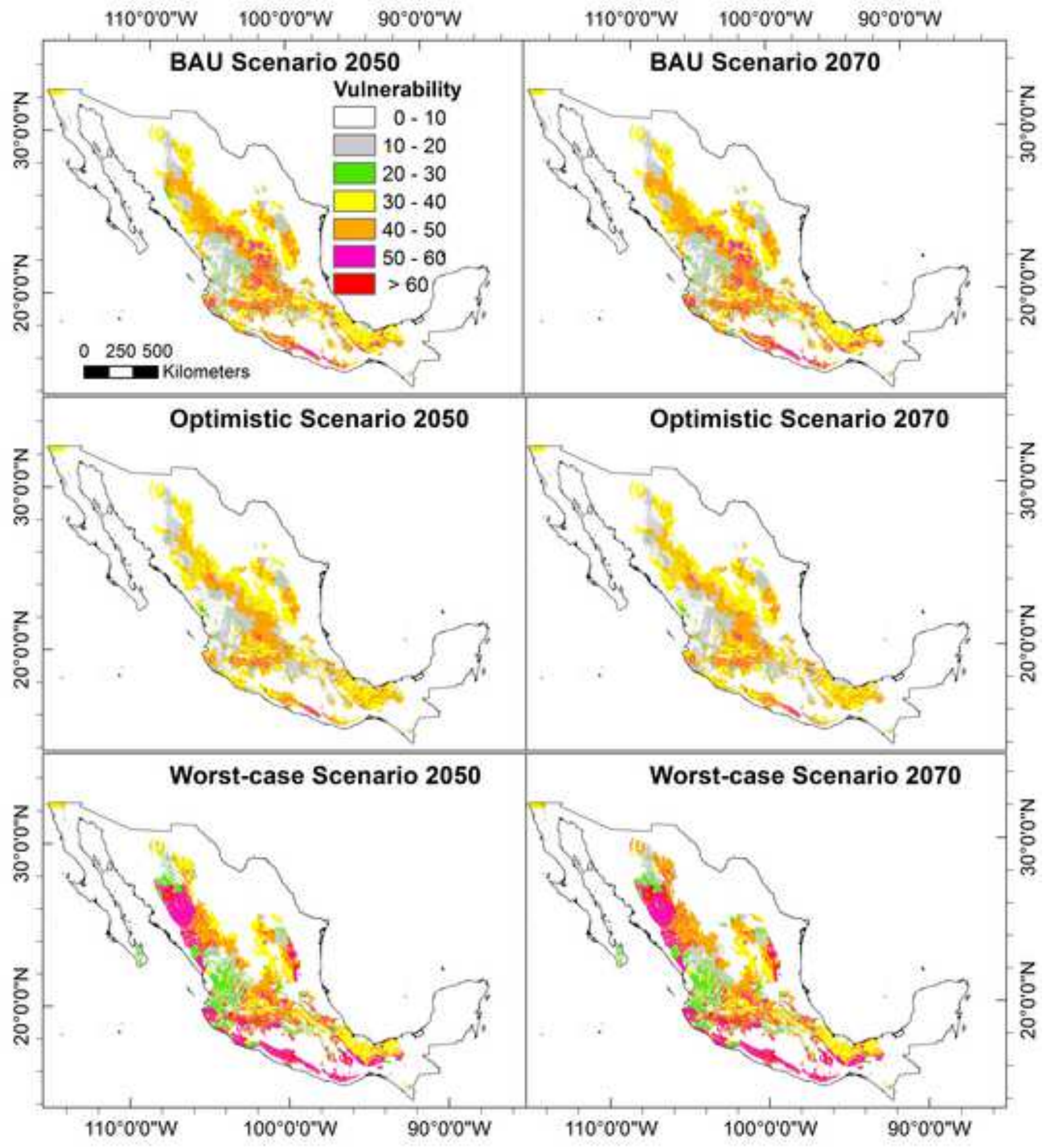


Highlights (for review)

- Global and national biodiversity studies suggest the need to preserve $45 \%$ of Mexico

- By 2050, $11.6 \%-16.1 \%$ of Mexico is vulnerable to LUCC and CC

- $30 \%$ of the most vulnerable areas are within 7 municipalities, $0.39 \%$ of Mexico 